\title{
A Meta-Analysis of the Prevalence of Toxoplasmosis in Live- stock and Poultry Worldwide
}

\author{
Bahador Hajimohammadi, ${ }^{1,2}$ Salman Ahmadian, ${ }^{3}$ Zohre Firoozi, ${ }^{2}$ Maryam Askari, ${ }^{4}$ \\ Masoud Mohammadi, ${ }^{5}$ Gilda Eslami D, ${ }^{1,3}$ Vahideh Askari, ${ }^{1}$ Elahe Loni, ${ }^{1}$ \\ Raziyeh Barzegar-Bafrouei, ${ }^{2}$ and Mohammad Javad Boozhmehrani ${ }^{3}$ \\ ${ }^{1}$ Research Center for Food Hygiene and Safety, Shahid Sadoughi University of Medical Sciences, Shohadaye Gomnam Blvd., Yazd 8916188638, Islamic \\ Republic of Iran \\ ${ }^{2}$ Department of Food Hygiene and Safety, School of Public Health, Shahid Sadoughi University of Medical Sciences, Yazd, Iran \\ ${ }^{3}$ Department of Parasitology and Mycology, School of Medicine, Shahid Sadoughi University of Medical Sciences, Yazd, Iran \\ ${ }^{4}$ Diabetes Research Center, Shahid Sadoughi University of Medical Sciences, Yazd, Iran \\ ${ }^{5}$ Cellular and Molecular Research Center, Gerash University of Medical Sciences, Gerash, Iran
}

\begin{abstract}
Toxoplasma gondii causes toxoplasmosis with a global prevalence in the world. A large proportion of human illness is most frequently associated with consuming raw and undercooked meat or other animal products containing infective parasitic stages of $T$. gondii. This systematic review and meta-analysis study evaluated the prevalence of toxoplasmosis in cattle, sheep, camels, goats, and poultry worldwide. The search was performed in databases including PubMed, WoS, Scopus, Science Direct, Google Scholar, and ISC from 2000 to 2019 in Persian and English. The main inclusion criteria were the prevalence of toxoplasmosis among livestock and poultry and the prevalence indices by sample size. During these 20 years, the overall prevalence of toxoplasmosis in livestock and poultry was $28.3 \%$ (95\% confidence interval (CI) 25-31.9\%) using the random-effects meta-analysis model. The highest prevalence of T. gondii in livestock and poultry animals was found in Asia in 2014 with 89.8\% (95\% CI 78.595.5\%). The lowest prevalence was found in Asia in 2013 with 1.26\% (95\% CI 0.4-3.8\%). A quarter of livestock and poultry were infected with $T$. gondii. Since livestock products are globally important sources of people's diet, our findings are useful for policymakers to control T. gondii infection in livestock.
\end{abstract}

Keywords: Toxoplasma gondii, Systematic review, Worldwide, Prevalence, Livestock animals

\section{INTRODUCTION}

Toxoplasma gondii is an obligate intracellular opportunistic parasite that is the causative agent of toxoplasmosis with a

Supplementary Information: The online version contains supplementary material available at https://doi.org/10.1007/s10393-022-01575-x.

Published online: February 8, 2022

Correspondence to: Gilda Eslami, e-mail: eslami_g2000@yahoo.com global prevalence in most parts of the world (Mammari et al. 2019). This zoonotic infection represents a major public health problem in human and veterinary medicine (Aguirre et al. 2019).

T. gondii infects a broad spectrum of warm-blooded vertebrates, including humans as intermediate hosts. On the other hand, cat family members (Felidae) are the only known definitive hosts of this infection (Dubey and Jones 2008). Besides, T. gondii has different forms of trophozoite, 
oocyst, and tissue cyst (Dubey et al. 1998). Most transmission routes that humans acquire toxoplasmosis are ingestion of oocysts (shed by infected cats) or tissue cysts of contaminated food or water and raw or semi-raw meat, respectively (Mosallanejad et al. 2011). Also, the consumption of infected raw milk is a possible route of tachyzoite transmission to humans (Koethe et al. 2017). Additionally, T. gondii can cross the placenta in some species, particularly humans, sheep, goats, camels, and cattle (Stelzer et al. 2019). These animals become easily infected through ingestion or inhalation of oocysts with food or water sources (Sharif et al. 2015). This parasite is involved in reproductive failure and production losses in livestock. As a result, toxoplasmosis in livestock animals is responsible for economic losses through death, abortion, and neonatal mortality.

It is estimated that 1.5 billion individuals are infected with this parasite worldwide. However, at least one-third of the world's human population has antibodies against Toxoplasma (Hill and Dubey 2013). Infection with T. gondii causes clinical manifestations of toxoplasmosis, including lymphadenopathy and blindness (Weiss and Dubey 2009). T. gondii infection in healthy adults is asymptomatic, but it has a greater impact on immunocompromised individuals (Wang et al. 2017).

Studies showed that the prevalence of infection caused by $T$. gondii in livestock varies greatly depending on the localities of the world (Dong et al. 2018; Holec-Gasior et al. 2013; Boughattas and Bouratbine 2014). Therefore, consuming contaminated meat and milk of infected animals can damage human health (Boughattas 2017; Dalir Ghaffari and Dalimi 2019; Boughattas and Bouratbine 2015). Because of the high importance of this issue, this systematic review with meta-analysis was performed to evaluate the prevalence of toxoplasmosis in cattle, sheep, camels, goats, and poultry worldwide.

\section{Methods}

\section{Search Strategy}

This study was conducted according to the preferred reporting items for systematic reviews and meta-analysis (PRISMA guideline 2009) (Moher et al. 2010). For this purpose, we conducted a systematic search of articles from English and Persian databases to address the prevalence of T. gondii infection in livestock animals (cattle, sheep, ca- mels, goats) and poultry all around the world. Data were collected from electronic databases, including PubMed, WoS, Scopus, Science Direct, Google Scholar, and Islamic World Science Citation (ISC) from 2000 to 2019. The inclusion criteria were the main epidemiological parameters of interest: the prevalence of toxoplasmosis among livestock and poultry and the prevalence indices by sample size. This research was conducted using the Medical Subject Headings (MeSH) terms as "Toxoplasma", "Toxoplasma gondii", "Toxoplasmosis", "T. gondii“", "Prevalence", "Goat", "Sheep", "Camel", "Cattle", "Toxoplasmosis in Animal", and "Livestock" combined using OR and/or AND.

\section{Selecting Studies and Data Extraction}

We searched all mentioned databases comprehensively; then, the relevant articles were selected based on the title and abstract content. Two independent reviewers evaluated the papers in parallel. If the article was rejected, the reason for the rejection was mentioned, and in the case of disagreement between the two reviewers, the third reviewer evaluated the article. The remaining articles were read in full text and screened for eligibility using a checklist of inclusion-exclusion criteria. The data, including title, year of publication, prevalence rate, location of study, the corresponding author, aims, main findings, sample size, and diagnostic methods, were extracted carefully from databases. Additionally, reference lists of published data were examined to extend the research and prevent missing additional studies.

\section{Statistical Analysis}

In each study, the prevalence of toxoplasmosis was obtained in livestock animals. The meta-analysis was performed using comprehensive meta-analysis software (Biostat, Englewood, NJ, USA) version 3. The heterogeneity of the studies was assessed by $I^{2}$ statistics. Heterogeneity was classified into three categories: heterogeneity less than 25\% (low level of heterogeneity), between 25 and 75\% (average level of heterogeneity), and more than 75\% (high level of heterogeneity). The probability of publication bias in the result was investigated using the funnel plot and Egger's test. Furthermore, publication bias in the results was measured using Begg and Mazumdar rank correlation test at a significance level of 0.1 due to the large sample size 


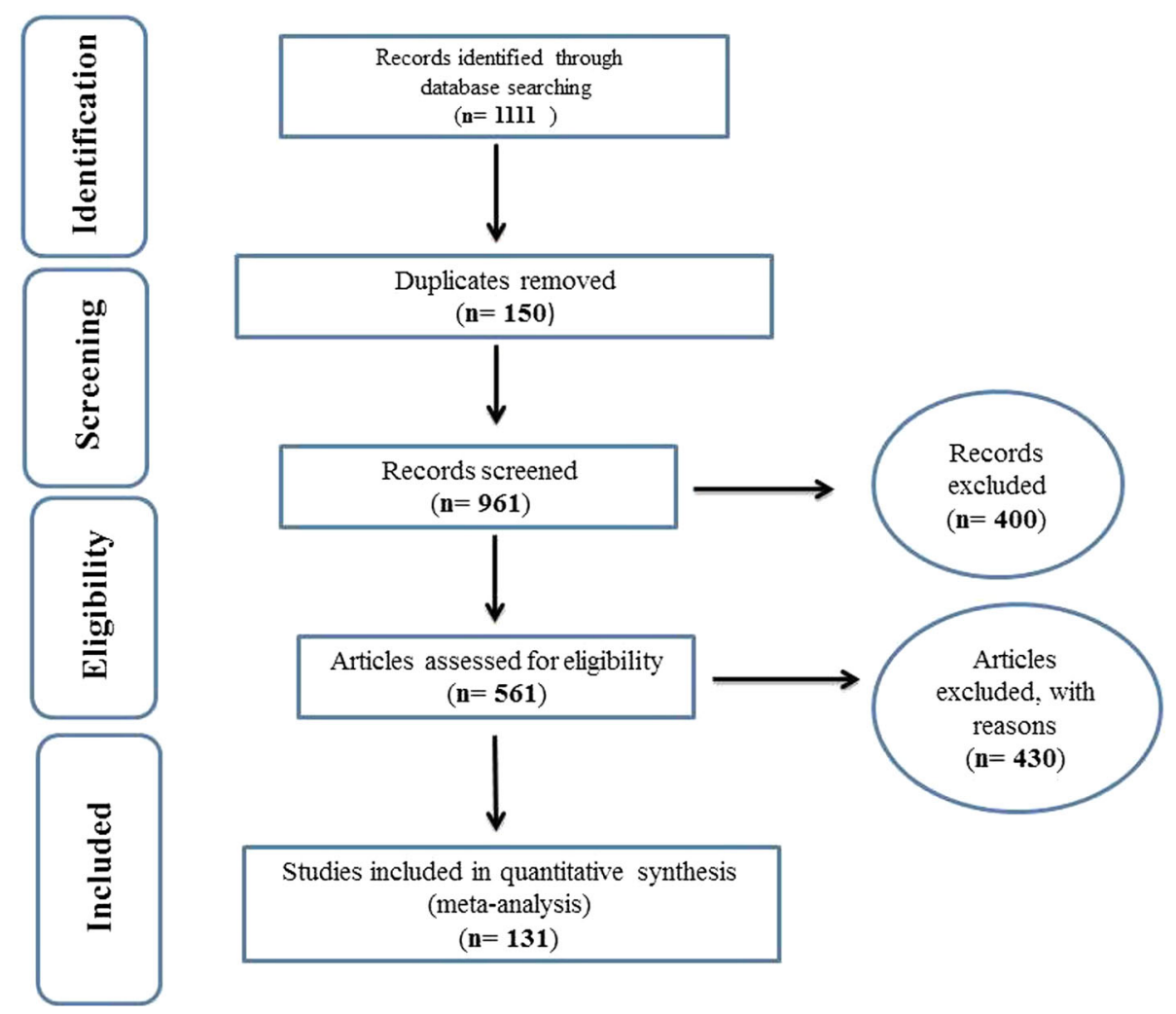

Figure 1. The flowchart on the stages of including the studies in the systematic review and meta-analysis (PRISMA 2009).

(Begg and Mazumdar 1994; Egger et al. 1997). Meta-regression was used for the sample size to investigate the effects of potentially effective factors on heterogeneity in the prevalence of $T$. gondii worldwide.

\section{Results}

\section{Search Output and Eligible Studies}

We identified 1111 documents following the initial literature search of national and international databases using relevant keywords; after removing 150 duplicated papers, the number of remaining articles decreased to 961 . A total of 400 irrelevant documents were excluded by reviewing the title and/or abstracts. Also, after a full-text review and using a checklist of inclusion-exclusion criteria, 430 irrelevant records were removed. Eventually, 131 articles were qualified to be included in this systematic review and metaanalysis, including 54 studies in Asia, 21 studies in Europe, 37 studies in Africa, 12 studies in South America, and seven studies in North America. A flow diagram depicting the study selection process is presented in Figure 1.

\section{Characteristics of the Eligible Studies}

Tables 1, 2, 3 and 4 show the characteristics of the final 131 articles eligible for inclusion which contain information from selected papers, including the name of the researcher, the year and place of the study, the number of samples, the kind of animal, diagnostic assay, and the prevalence of $T$. gondii in the studies. Our analysis contains 61,716 infected animals from 45 countries and five continents. The maximum sample size was related to the study conducted by Verhelst et al. (2014) in Belgium (3170 sheep), and the minimum sample size $(\mathrm{n}=24$, goat $)$ was reported from Japan by Kyan et al. (2012). The diagnostic methods used in eligible studies were enzyme-linked immunosorbent assay (ELISA), indirect fluorescent antibody test (IFA), total lysate antigens (TLA), direct agglutination test (DAT), modified agglutination test (MAT), latex agglutination test (LAT), polymerase chain reaction (PCR), nested PCR, and real-time PCR.

\section{Heterogeneity and Publication Bias}

The heterogeneity of the studies was evaluated using the $I^{2}$ test, and the results showed $I^{2}=98 \%$. The high I-squares 
Table 1. Baseline Characteristics of Selected Studies Reporting Seroprevalence of T. gondii in Animals in Europe.

\begin{tabular}{|c|c|c|c|c|c|}
\hline Authors (References) & Country & Kind of animals & Diagnostic method & Sample size & Prevalence $(\%)$ \\
\hline Deng et al. (2016) & Netherlands & Dairy goat & ELISA & 1664 & 13.3 \\
\hline Lorencová et al. (2016) & Czech & Goat, lamb & ELISA, real-time PCR & 57 & 28.07 \\
\hline Lopes et al. (2015) & Portugal & Cattle, sheep, goat & Nested PCR & 75 & 68 \\
\hline Sechi et al. (2013) & Italy & Sheep & IFA & 630 & 33.97 \\
\hline Misurova et al. (2009) & Czech & Goat & IFA & 28 & 82.1 \\
\hline Cenci-Goga et al. (2013) & Italy & Sheep & IFA & 630 & 34 \\
\hline Balea et al. (2012) & Romania & Sheep, goat & ELISA & 513 & 44.2 \\
\hline Moskwa et al. (2018) & Poland & Sheep, goat & ELISA & 103 & 36.8 \\
\hline Roqueplo et al. (2011) & France & Cattle & ELISA & 30 & 3.3 \\
\hline Tzanidakis et al. (2012) & Greece & Sheep, goat & ELISA & 2042 & 43.8 \\
\hline Garcia et al. (2013) & Spain & Cattle, sheep, goat & ELISA & 1501 & 52.56 \\
\hline Luptakova et al. (2015) & Slovakia & Ewes & real-time PCR, ELISA & 80 & 31.25 \\
\hline Verhelst et al. (2014) & Belgium & Sheep & ELISA (TLA), IFA & 3170 & 87.4 \\
\hline Sroka et al. (2017) & Poland & Goat & DAT, Nested - PCR, real- time PCR & 73 & 70 \\
\hline Vismarra et al. (2016) & Italy & Chicken & ELISA & 66 & 36.4 \\
\hline Villena et al. (2012) & France & Ovine & ELISA, MAT, Bioassay & 419 & 27 \\
\hline Diakoua et al. (2013) & Greece & Sheep, goat & ELISA & 833 & 57.1 \\
\hline Iovu et al. (2012) & Romania & Dairy goat & ELISA & 735 & 52.8 \\
\hline Morley et al. (2008) & UK & Sheep & PCR & 29 & 31 \\
\hline Djokic et al. (2014) & Serbia & Goat & MAT & 431 & 73.3 \\
\hline Stormoen et al. (2012) & Norwegian & Dairy goat & DAT & 2188 & 17 \\
\hline
\end{tabular}

ELISA enzyme-linked immunosorbent assay, IFA indirect fluorescent antibody, TLA total lysate antigen, DAT direct agglutination test, MAT modified agglutination test, $P C R$ polymerase chain reaction.

indicate considerable heterogeneity between the results. Therefore, a random-effects model was used to combine the results of the studies. The funnel plot indicated no publication bias, and Beggs and Egger's tests were not statistically significant $(P=0.890)$ (Fig. 2).

\section{Meta-Analysis}

In this 20-year survey, the prevalence of toxoplasmosis in livestock and poultry in the continents of Asia, Africa, America (North and South), and Europe was 21.7\% (95\% CI $18.3-25.6 \%$ ), 29\% (95\% CI 23.9-34.7\%), 16.4\% (95\% CI $8.6 \%-29 \%$ ), 38.5\% (95\% CI 31-46.5\%), and $43.5 \%$ (95\% CI 32.1-55.6\%), respectively (Figs. 3, 4, 5, 6, 7); and the overall prevalence using the random-effects metaanalysis model was $28.3 \%$ (95\% CI 25-31.9\%) (Fig. 8). The highest prevalence of $T$. gondii in livestock and poultry was in Iran and Asia in 2014 with 89.8\% (95\% CI 78.5-95.5\%), while the lowest prevalence was also in Iran and Asia in 2013 with $1.26 \%$ (95\% CI $0.4-3.8 \%$ ). It should be men- tioned that the prevalence rate of this parasite in India (2017) was $1.5 \%$.

In Figures 3, 4, 5, 6, 7 and 8, test displays the prevalence of toxoplasmosis based on the random-effects model, with black squares representing the prevalence, square section length showing 95\% CI in each study, and the diamond sign indicating the total prevalence in the country for all studies. The studies' range in the chart is considered between 1 and -1 . As can be seen in the figures, the prevalence values are positive and greater than zero.

\section{Meta-Regression}

Meta-regression was used for the sample size to investigate the effects of potentially effective factors on heterogeneity in the prevalence of toxoplasmosis in livestock and poultry in the world (Fig. 9). The prevalence of T. gondii infection increases with the growing sample size in the studies, and statistically significant differences were found $(P<0.05)$. 
Table 2. Baseline Characteristics of Selected Studies Reporting Seroprevalence of T. gondii in Animals in Asia.

\begin{tabular}{|c|c|c|c|c|c|}
\hline Authors (references) & Country & Kind of animals & Diagnostic method & $\begin{array}{l}\text { Sample } \\
\text { size }\end{array}$ & $\begin{array}{l}\text { Prevalence } \\
\quad(\%)\end{array}$ \\
\hline Olfaty-Harsini et al. (2017) & Iran & Ewe & Nested PCR & 60 & 48.3 \\
\hline Havakhah et al. (2014) & Iran & Sheep, goat & Sabin-Feldman Dye & 402 & 27.6 \\
\hline $\begin{array}{l}\text { Akhoundi and Youssefi } \\
\text { (2017) }\end{array}$ & Iran & Sheep & IFA & 764 & 28.2 \\
\hline Sharif et al. (2005) & Iran & Cattle, sheep, goat & IFA & 1278 & 25.4 \\
\hline Khamesipour et al. (2014) & Iran & Cattle, camel, sheep & PCR & 372 & 6.7 \\
\hline Azizi et al. (2014) & Iran & Sheep, cattle & PCR & 120 & 20.8 \\
\hline Sarkari et al. (2014) & Iran & reared turkey & PCR, MAT, Bioassay & 54 & 89.8 \\
\hline Tavakoli et al. (2017) & Iran & Sheep, goat & Nested - PCR & 240 & 50.4 \\
\hline Ghazaei (2006) & Iran & Cattle, sheep, goat, chicken & ELISA & 750 & 14.4 \\
\hline Hamidinejat et al. (2009) & Iran & Cattle & MAT & 450 & 15.7 \\
\hline Asgari et al. (2011) & Iran & Sheep, goat & Nested - PCR & 78 & 33.3 \\
\hline Dehkordi et al. (2013) & Iran & $\begin{array}{l}\text { Caprin, ovine, buffalo, camel, bo- } \\
\text { vine }\end{array}$ & $\begin{array}{l}\text { Bioassay, ELISA, } \\
\text { PCR }\end{array}$ & 889 & 27.1 \\
\hline Razmi et al. (2010) & Iran & Ovine & IFA & 325 & 5.2 \\
\hline Tavassoli et al. (2013) & Iran & Sheep, goat & PCR & 237 & 1.26 \\
\hline Asgari et al. (2009a, b) & Iran & Chicken & IFA, Nested-PCR & 231 & 25 \\
\hline Asgari et al. (2006) & Iran & Chicken & IFA & 122 & 36.1 \\
\hline Hamidinejat et al. (2008) & Iran & Ewe & ELISA, MAT & 150 & 72.6 \\
\hline Hamidinejat et al. (2013) & Iran & Camel & MAT & 254 & 14.5 \\
\hline Kavari et al. (2013) & Iran & Sheep, goat & ELISA, Nested PCR & 186 & 18.3 \\
\hline Asgari et al. $(2009 a, b)$ & Iran & Sheep & IFA & 603 & 26.5 \\
\hline Gorji et al (2018) & Iran & Sheep & Nested - PCR & 140 & 18.5 \\
\hline Mahami et al. (2017) & Iran & Beef, chicken, lamb & PCR & 150 & 17.3 \\
\hline Armand et al. (2016) & Iran & Sheep & $\begin{array}{l}\text { ELISA, Nestad - } \\
\quad \text { PCR }\end{array}$ & 370 & 35.9 \\
\hline Wiengcharoen et al. (2012) & Thailand & Cattle & IFA & 389 & 25.7 \\
\hline Ge et al. (2014) & China & Cattle & ELISA, Nested, RFLP & 1040 & 12.8 \\
\hline Khlaty et al. (2015) & Iraq & Sheep & LAT, PCR & 300 & 33.3 \\
\hline Akhtar et al. (2014) & Pakistan & Chicken & LAT, Bioassay & 300 & 36.3 \\
\hline Ahmad et al. (2014) & Pakistan & Cattle, buffalo & ELISA & 822 & 17.3 \\
\hline Wang et al. (2011) & China & Sheep, goat & IHA & 1270 & 3.3 \\
\hline Lashari et al. (2010) & Pakistan & Sheep & LAT, ELISA & 518 & 19.8 \\
\hline Jung et al. (2014) & Korean & Goat & ELISA & 610 & 5.1 \\
\hline Bawmet al. (2016) & Myanmar & Goat & LAT & 281 & 11.4 \\
\hline Shah et al. (2013) & Pakistan & Goat, sheep & IHA & 640 & 42.8 \\
\hline Qiu et al. (2012) & China & Cattle & IHA & 1803 & 2.6 \\
\hline Oncel et al. (2006) & Turkey & Sheep & ELISA & 181 & 31 \\
\hline Giangaspero et al. (2013) & Japan & Sheep & ELISA & 267 & 28.7 \\
\hline Sharma et al. (2008) & India & Sheep, cattle, buffalo & ELISA & 372 & 3.2 \\
\hline Kyan et al. (2012) & Japan & Goat & RFLP, LAT & 24 & 75 \\
\hline Matsuo et al. (2014) & Japan & Cattle, chicken & LAT & 657 & 4.7 \\
\hline Alanazi et al. (2013) & $\begin{array}{l}\text { Saudi Ara- } \\
\text { bia }\end{array}$ & Sheep, goat, camel & IFA & 1628 & 34.6 \\
\hline Jittapalapong et al. (2005) & Thailand & Goat & LAT & 631 & 27.9 \\
\hline Zou et al. (2015) & China & Buffalo, sheep, goat & IHA & 973 & 11.9 \\
\hline
\end{tabular}


Table 2. continued

\begin{tabular}{|c|c|c|c|c|c|}
\hline Authors (references) & Country & Kind of animals & Diagnostic method & Sample size & Prevalence $(\%)$ \\
\hline lchikawa et al. (2015) & Indonesia & Cattle, pig & ELISA & 803 & 9.2 \\
\hline Singh et al. (2015) & India & Sheep, goat, cattle & PCR, ELISA, IFA & 168 & 50.5 \\
\hline Luo et al. (2017) & China & Cattle, goat, buffalo & IHA & 935 & 14.2 \\
\hline Kalambhe et al. (2017) & India & Sheep, goats & Nested- PCR & 400 & 1.5 \\
\hline Zhou et al. (2016) & Turkey & Sheep, goat, cattle & ELISA & 1236 & 13.6 \\
\hline Celik et al. (2018) & Turkey & Cattle & ELISA & 300 & 18 \\
\hline Bachan et al. (2018) & India & Goat & ELISA, IFA & 445 & 42.4 \\
\hline Chikweto et al. (2011) & India & Sheep, goat, cattle & MAT & 503 & 35.1 \\
\hline Sunanta et al. (2009) & Thailand & Dairy cow & ELISA, IFAT, LAT, PCR & 50 & 54 \\
\hline Aktas et al. (2000) & Turkey & Sheep & Sabin-Feldman (SF) & 154 & 46.8 \\
\hline Al-Rammahi et al. (2010) & Iraq & Cattle, sheep, goat & LAT & 745 & 36.7 \\
\hline Al-dabagh et al. (2014) & Iraq & Sheep & ELISA & 100 & 32 \\
\hline
\end{tabular}

IFA indirect fluorescent antibody, PCR polymerase chain reaction, MAT modified agglutination test, ELISA enzymed-linked immunosorbent assay, RFLP restriction fragment length polymorphism, LAT latex agglutination test, IHA indirect haemagglutination test.

\section{DISCUSSION}

Toxoplasmosis is considered one of the most widespread zoonotic diseases around the globe that were mainly transmitted to humans via consuming contaminated food (water and vegetables) with oocysts and eating the meat of livestock and poultry harboring tissue cysts (Mosallanejad et al. 2011). Recently, the consumption of raw and semiraw meat and dairy products has been increasing worldwide. Hence, the safety assessment of livestock and poultry products is worthwhile for public health policymakers. To the best of our knowledge, this is the first meta-analysis to review and evaluate the prevalence of $T$. gondii in livestock (sheep, goats, camels, and cattle) and poultry considering different countries and continents from 2000 to 2019.

According to this meta-analysis, the overall global prevalence of toxoplasmosis in livestock and poultry was 28.3\%. This prevalence rate is higher than Toxoplasma seroprevalence in pigs (19\%) reported by Foroutan (Foroutan et al. 2019). This difference could be explained by the fact that pork consumption is forbidden in Muslim countries, and they mostly consume cattle, sheep, camel, goat, and poultry products.

Also, the highest prevalence rate of toxoplasmosis was $89.8 \%$, while the lowest prevalence was $1.26 \%$. The worldwide prevalence of toxoplasmosis differs from $16.4 \%$ in North America to $43.5 \%$ in Europe. In previous studies, the toxoplasmosis prevalence has been reported in coun- tries worldwide from 10 to $90 \%$ (Torgerson and Mastroiacovo 2013). These variations can be explained by climate, different characteristics of the studies (sample size and various diagnostic serological methods), animal production systems, and specific control measures.

Climatic variations (temperature and humidity) in different parts of the world can cause different prevalences of the parasite (Rostami et al. 2017). The prevalence of Toxoplasma in livestock has been studied in most parts of the world for the last 20 years that could be a reason for the heterogeneity in the astonishing findings found. One research has reported that the prevalence of toxoplasmosis is higher in temperate climate and low-altitude regions. Besides, they reported that the prevalence is lower in cold and hot and dry areas (Rahimi et al. 2015). Oocytes do not grow in hot and dry climates, leading to a low prevalence of toxoplasmosis in such areas. Thus, it can be concluded that infections in cats are different among various regions concerning the climate. Our results also demonstrated a significant influence of geographical and climate factors on T. gondii seroprevalence so that decreasing and increasing seroprevalence was reported from North and South America, respectively, even though the number of studies was different in North and South America. Moreover, its prevalence in the Middle East $(26.4 \%)$ differs from other Asian countries (17.8\%). (Supplementary file).

With respect to diagnostic methods, our findings suggest that the diagnostic methods may be a source of 
Table 3. Baseline Characteristics of Selected Studies Reporting Seroprevalence of T. gondii in Animals in Africa.

\begin{tabular}{|c|c|c|c|c|c|}
\hline Authors (references) & Country & Kind of animals & $\begin{array}{l}\text { Diagnostic meth- } \\
\text { od }\end{array}$ & Sample size & Prevalence (\%) \\
\hline Gebremedhin et al. (2013) & Ethiopia & Sheep, goat & ELISA & 1372 & 31.8 \\
\hline Swai et al. (2012) & Tanzania & Dairy goat & LAT & 337 & 19.3 \\
\hline Mose et al. (2016) & Kenya & Chicken & Nested - PCR & 105 & 79 \\
\hline Ayinmode et al. (2016) & Nigeria & Cattle, sheep, goat & ELISA & 883 & 22.2 \\
\hline Amairia et al. (2016) & Tunisia & Goat & $\begin{array}{l}\text { ELISA,Nested- } \\
\text { PCR }\end{array}$ & 77 & 31.2 \\
\hline Rouatbi et al. (2017) & Tunisia & Sheep & Nested - PCR & 324 & 31.4 \\
\hline Kamani et al. (2009) & Nigeria & Sheep, goat & ELISA & 744 & 5.6 \\
\hline Lazim et al. (2018) & Sudan & Cattle, sheep, goat & LAT & 191 & 16.8 \\
\hline Ibrahim et al. (2014) & Sudan & Dairy cow & ELISA & 131 & 89.3 \\
\hline Samra et al. (2007) & South Africa & Sheep & IFA - ELISA & 600 & 4.3 \\
\hline Gebremedhin and Gizaw (2014) & Ethiopia & Sheep, goat & ELISA & 184 & 26.08 \\
\hline Hammond et al. (2015) & South Africa & Sheep & ELISA & 292 & 8 \\
\hline Atail et al. (2017) & Sudan & Sheep, goat & LAT, iELISA & 400 & 52 \\
\hline Al-kappany et al. (2018) & Egyptian & Sheep, goat & IFA, ELISA & 498 & 24.5 \\
\hline Onyiche et al. (2015) & Nigeria & Cattle & ELISA & 210 & 13.81 \\
\hline Khalil et al. (2011) & Sudan & Camel, cattle, sheep & LAT & 200 & 38 \\
\hline Tilahun et al. (2018) & Ethiopia & Sheep, goat, cattle, camel & ELISA & 1360 & 22.2 \\
\hline Amdouni et al. (2017) & Tunisia & Sheep, goat, cattle & PCR & 420 & 28.09 \\
\hline Elfahal et al. (2013) & Sudan & Dairy cattle & ELISA & 181 & 13.3 \\
\hline Van der puije et al. (2000) & Ghana & Sheep, goat & ELISA, IFA & 1258 & 30.5 \\
\hline Davoust et al. (2015) & Senegal & Bovine, ovine, caprin & MAT & 198 & 14.1 \\
\hline Gebremedhin et al. (2014) & Ethiopia & Sheep, goat & DAT & 628 & 17.6 \\
\hline Lahmar et al. (2015) & Tunisia & Sheep, cattle, goat & MAT, PCR & 261 & 36.8 \\
\hline Sawadogo et al. (2005) & Morocco & Sheep & ELISA & 261 & 27.6 \\
\hline Dechicha et al. (2015) & Algeria & Cattle, sheep, goat & IFA & 714 & 8.2 \\
\hline Abdel-Hafeez et al. (2015) & Egypt & Cattle, goat & IHA & 200 & 50.9 \\
\hline Abdel-Rahman et al. (2012) & Egypt & Caprine & IHA & 182 & 42.3 \\
\hline Aboelhadid et al. (2013) & Egypt & Chicken & MAT & 215 & 13.95 \\
\hline Anwar et al. (2013) & Egypt & Sheep & Necropsy & 60 & 18.3 \\
\hline El-Massry et al. (2000) & Egypt & Turkey, chicken, duck & MAT & 329 & 54.1 \\
\hline Fereig et al. (2016) & Egypt & Sheep, goat, cattle & LAT, ELISA & 506 & 27.8 \\
\hline Saad et al. (2018) & Egypt & Goat, sheep, camel & ELISA and $\mathrm{qPCR}$ & 90 & 51.11 \\
\hline Ahmed et al. (2017) & Egypt & Camel & ELISA & 120 & 52.5 \\
\hline Dubey et al. (2003a, b) & Egypt & Chicken & MAT & 121 & 40.4 \\
\hline Ibrahim et al. (2016) & Egypt & Chicken & ELISA & 304 & 11.18 \\
\hline Ibrahim et al. (2017) & Egypt & Sheep & ELISA & 170 & 51.76 \\
\hline Kuraa et al. (2016) & Egypt & Camel, cattle buffaloes, sheep, goat & ELISA & 274 & 83.6 \\
\hline
\end{tabular}

ELISA enzyme-linked immunosorbent assay, LAT latex agglutination test, IFA indirect fluorescent antibody, PCR polymerase chain reaction, DAT direct agglutination test.

heterogeneity. A fluctuation in outcomes was observed in studies; e.g., in Iran, Akhoundi and Youssefi (2017) reported $28.2 \%$ of infection prevalence using the IFA method in Northern Iran, while Tavakoli et al. (2017) reported $50.4 \%$ using PCR methods in Eastern Iran. However, it should be taken into consideration that these studies were conducted in different sample sizes and areas.

Our findings demonstrated an association between the prevalence of $T$. gondii and sample size. In the current meta-analyses, we observed that $T$. gondii prevalence in- 
Table 4. Baseline Characteristics of Selected Studies Reporting Seroprevalence of T. gondii in Animals in America.

\begin{tabular}{|c|c|c|c|c|c|}
\hline Authors (references) & Country & Kind of animals & Diagnostic method & Sample size & Prevalence $(\%)$ \\
\hline \multicolumn{6}{|l|}{ North America } \\
\hline Persad et al. (2011) & Trinidad & Water buffalo & LAT & 333 & 7.8 \\
\hline Alvarado et al. (2013a; b) & Mexico & Dairy goat & MAT & 341 & 15.2 \\
\hline Alvarado et al. (2013a; b) & Mexico & Sheep & MAT & 429 & 23.1 \\
\hline Dubey et al. (2011) & USA & Goat & MAT - Bioassay & 234 & 53.4 \\
\hline Gebreyes et al. (2008) & USA & Swine & ELISA & 675 & 7 \\
\hline Dubey et al. (2008) & USA & Sheep & MAT, PCR, Bioassay & 383 & 27.1 \\
\hline Yaglom et al. (2014) & USA & Boer goat & LAT & 367 & 6.8 \\
\hline \multicolumn{6}{|l|}{ South America } \\
\hline Dubey et al. (2004) & Peru & Chicken & MAT - Bioassay & 50 & 28 \\
\hline Dubey et al. (2003a, b) & Brazil & Chicken & MAT, Bioassay & 40 & 40 \\
\hline Franco et al. (2016) & Colombia & Beef, chicken & PCR & 120 & 45.8 \\
\hline Lopes et al. (2016) & Brazil & Chicken & MAT, ELISA, PCR & 108 & 71.3 \\
\hline Figliuolo et al. (2004) & Brazil & Goat & IFA & 394 & 28.7 \\
\hline Romanelli et al. (2007) & Brazil & Sheep & MAT & 305 & 51.5 \\
\hline Dubey et al. (2002) & Brazil & Chicken & MAT - Bioassay & 82 & 39 \\
\hline Moraes et al. (2011) & Brazil & Goat, sheep & IFA & 110 & 12.7 \\
\hline Guimaraes et al. (2013) & Brazil & Sheep & IFA & 795 & 30.2 \\
\hline Da Silva et al. (2014) & Brazil & Ovine(sheep) & IFA & 40 & 45 \\
\hline Frazao et al. (2011) & Brazil & Cattle & ELISA & 77 & 49.4 \\
\hline Neto et al. (2008) & Brazil & Goat & IFA & 366 & 30.6 \\
\hline
\end{tabular}

LAT latex agglutination test, MAT modified agglutination test, ELISA enzymed-linked immunosorbent assay, PCR polymerase chain reaction, IFA indirect fluorescent antibody.

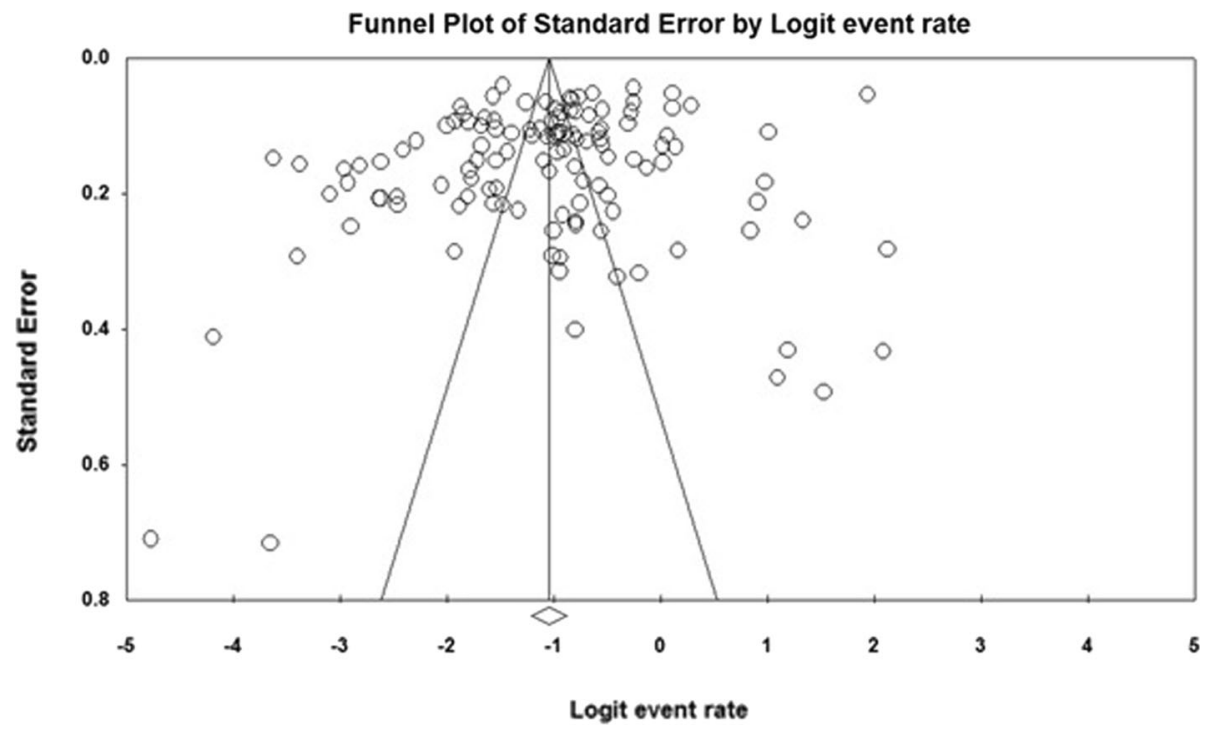

Figure 2. Funnel plot. Results of toxoplasmosis prevalence in livestock and poultry animals worldwide. 


\section{Meta Analysis}

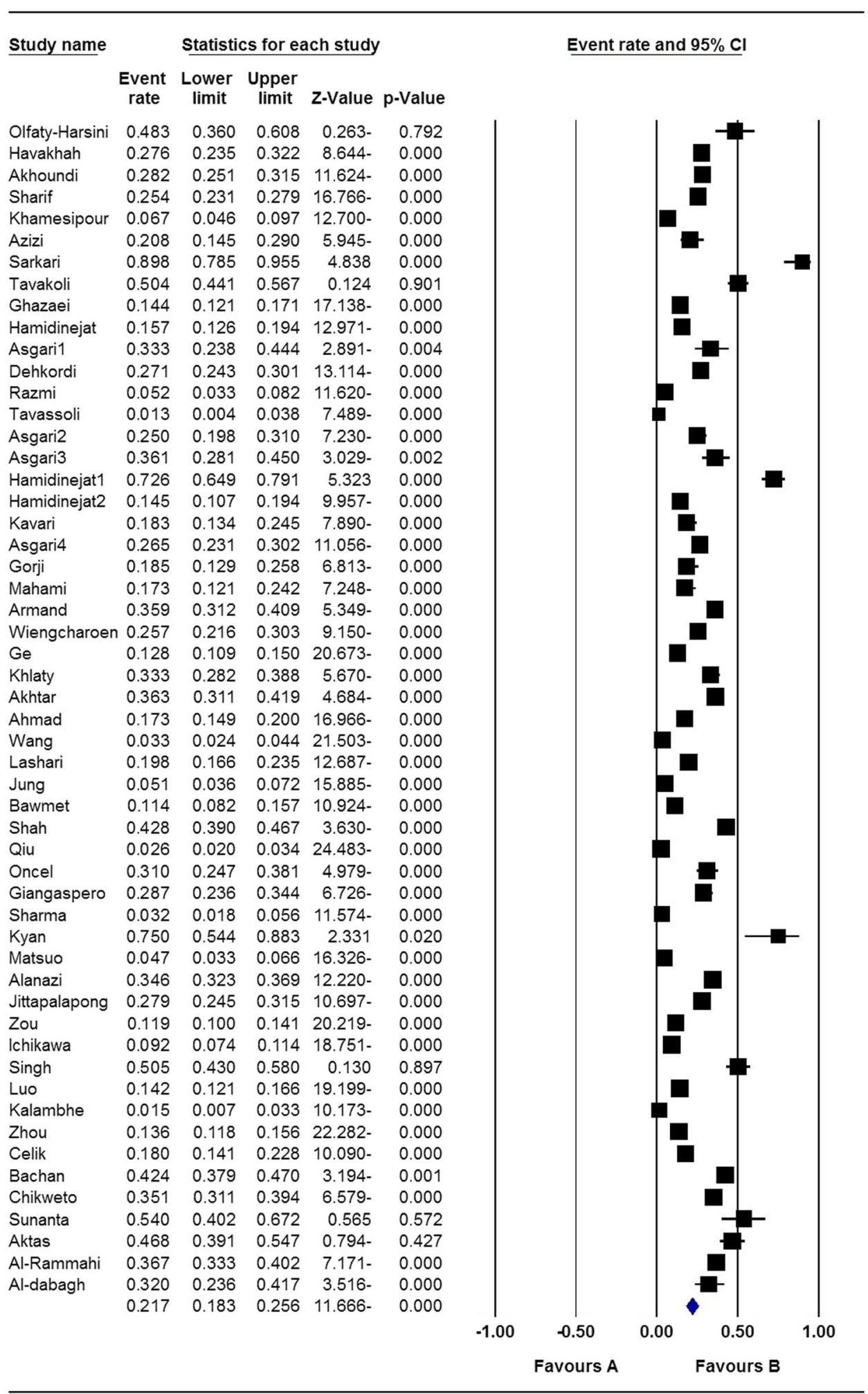

\section{Meta Analysis}

Figure 3. The forest plot of prevalence of toxoplasmosis in livestock and poultry: meta-analysis plot of toxoplasmosis in Asia. 
Meta Analysis

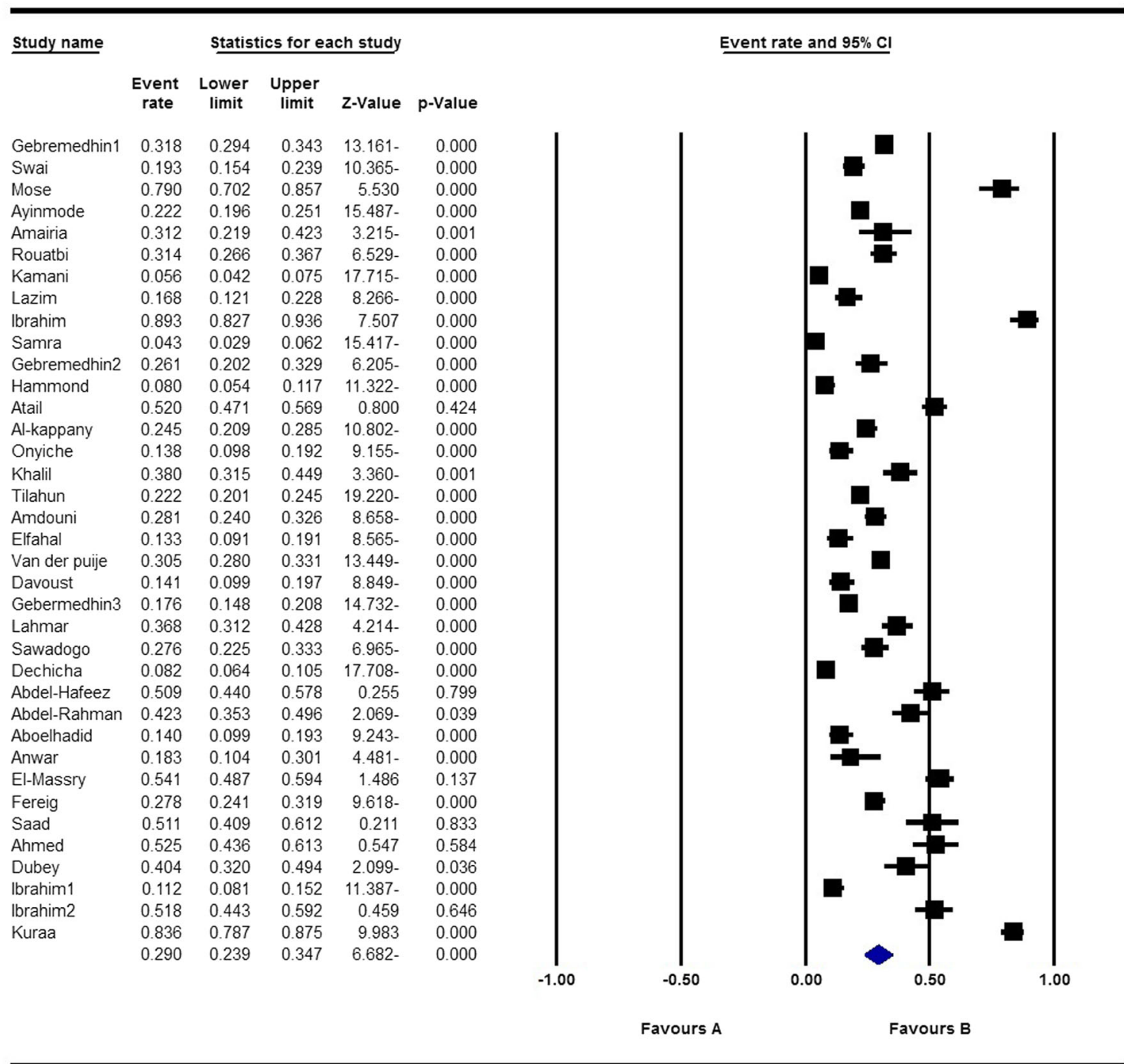

Meta Analysis

Figure 4. The forest plot of prevalence of toxoplasmosis in livestock and poultry: meta-analysis plot of toxoplasmosis in Africa.

creases with growing the sample size. This increase could be due to raising the number of animals exposed to the parasite.

Considering previous meta-analyses, it can be acknowledged that a low level of health is an effective factor for increasing the prevalence of toxoplasmosis in Africa. Also, Hotez (2014) explained that toxoplasmosis is highly prevalent in poor areas because of low health literacy (Hotez 2014). Several studies have shown that good hygiene in the manufacturing of farms under intensive management practice can significantly decrease the prevalence of $T$. gondii, but a developing country cannot exploit these facilities (De Berardinis et al. 2017; Robert-Gangneux and Darde 2012). According to our results, contrary to surveys done in Africa, advanced countries like Belgium also have high infection levels. Therefore, more critical factors contribute to the prevalence of this infection, which requires further study. This result indicates that the prevalence of toxoplasmosis is dependent not only on the poor condition of countries and socioeconomic factors but also on the different environmental factors.

The study strengths are the large total sample size, comprehensive article search, and subgroup analyses. Moreover, this study included the accurate and strict methodology and quality assessment that two independent reviewers performed. However, this study had some limi- 
Meta Analysis

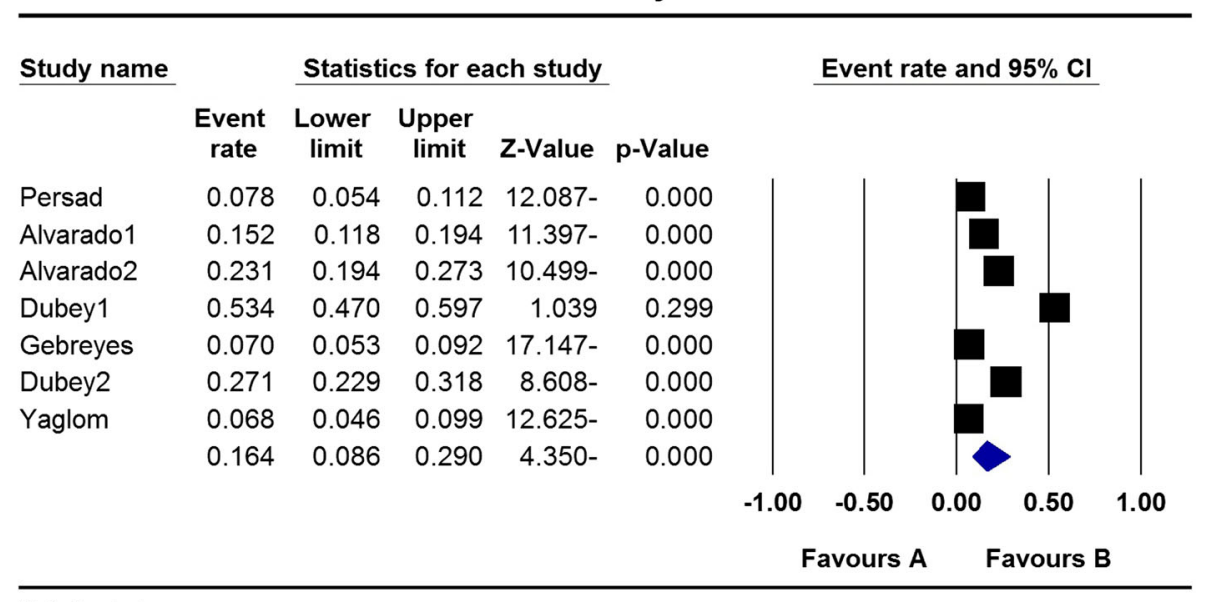

Meta Analysis

Figure 5. The forest plot of prevalence of toxoplasmosis in livestock and poultry: meta-analysis plot of toxoplasmosis in North America.

Meta Analysis

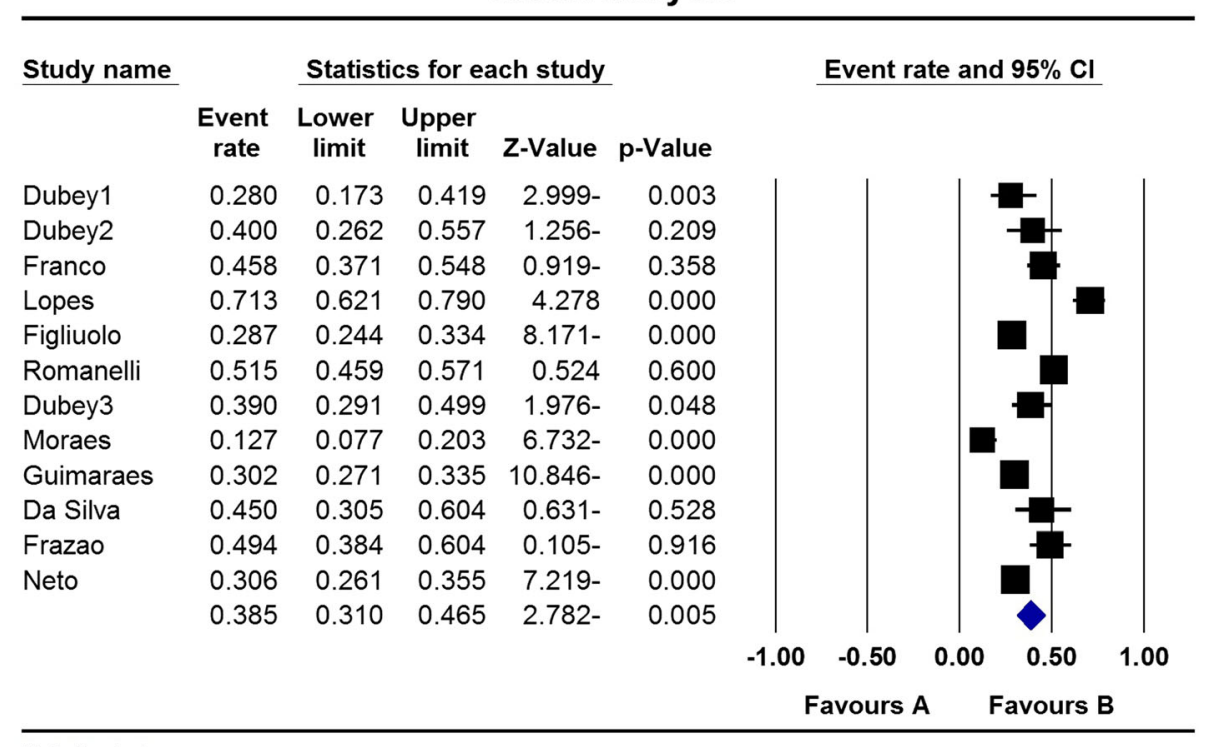

Meta Analysis

Figure 6. The forest plot of prevalence of toxoplasmosis in livestock and poultry: meta-analysis plot of toxoplasmosis in South America.

tations, including no review of the effect of age and sex on the infection prevalence and high heterogeneity and variations in sensitivity and specificity of diagnostic methods (bioassay and serological methods).

\section{CONCLUSION}

It was found that more than a quarter of livestock animals and poultry are infected with $T$. gondii. Since livestock products are globally important sources of people's diet 


\section{Meta Analysis}

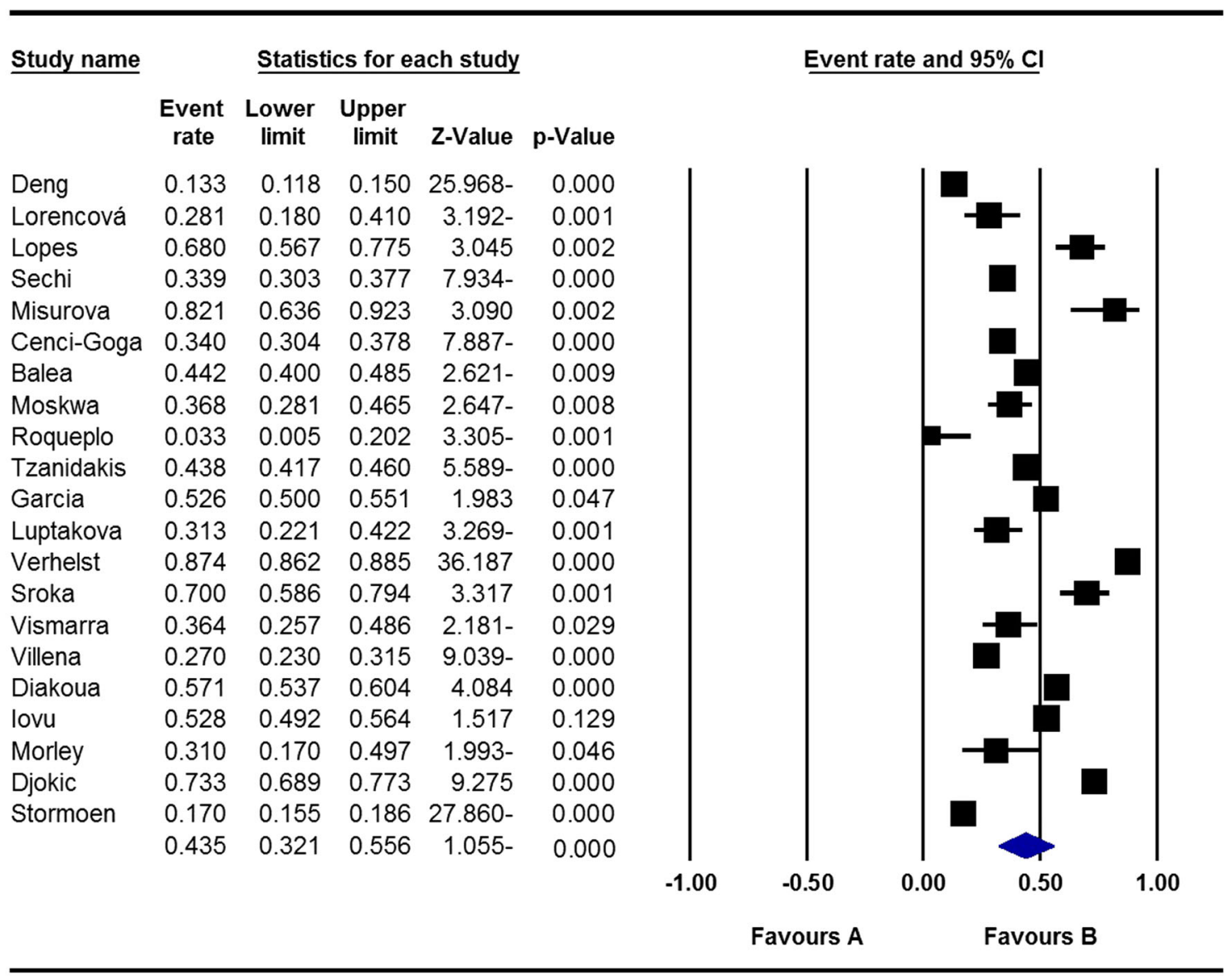

Meta Analysis

Figure 7. The forest plot of prevalence of toxoplasmosis in livestock and poultry: meta-analysis plot of toxoplasmosis in Europe. 
Meta Analysis

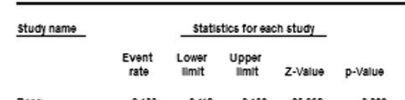

$\begin{array}{llllll}\text { Deng } & 0.133 & 0.118 & 0.150 & 25568 & 0000 \\ \text { Loressos } & 0.231 & 0.120 & 0.410 & 3.192- & 0.001\end{array}$

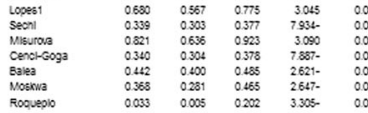

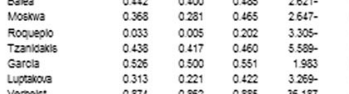

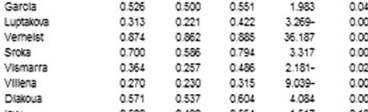

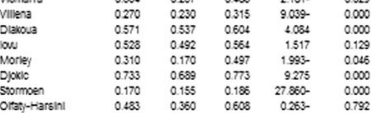

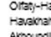

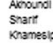

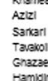

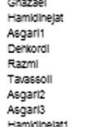

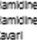

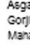

Amerovers

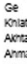

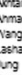

$\operatorname{ling}_{\sin }$

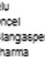

\section{then}

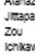

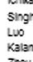

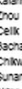

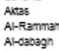

Georem

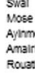

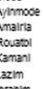

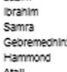

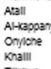

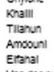

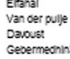

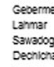

先

Sacters

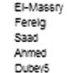

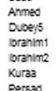

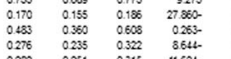

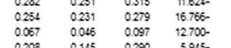

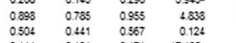

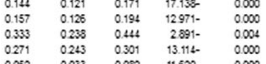

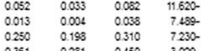

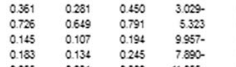

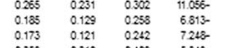

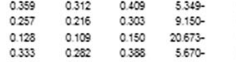

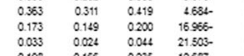

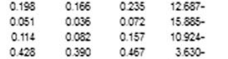

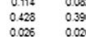

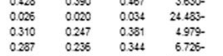

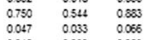

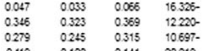

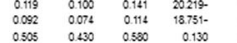

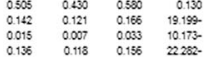

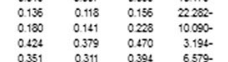

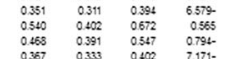

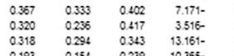

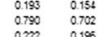

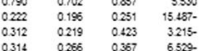

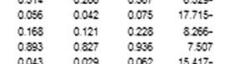

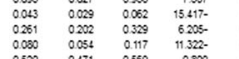

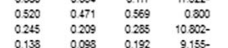

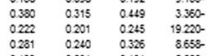

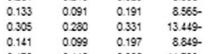

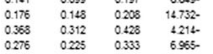

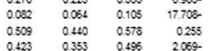

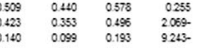

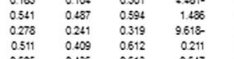

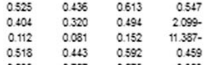

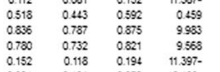

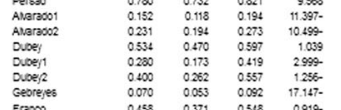

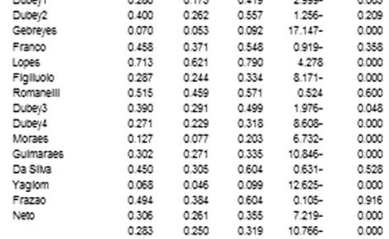

Event tat and a $95 \%$ C1
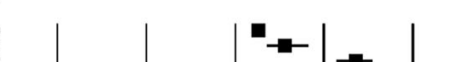

Figure 8. The forest plot of prevalence of toxoplasmosis in livestock and poultry: meta-analysis plot of toxoplasmosis worldwide. 


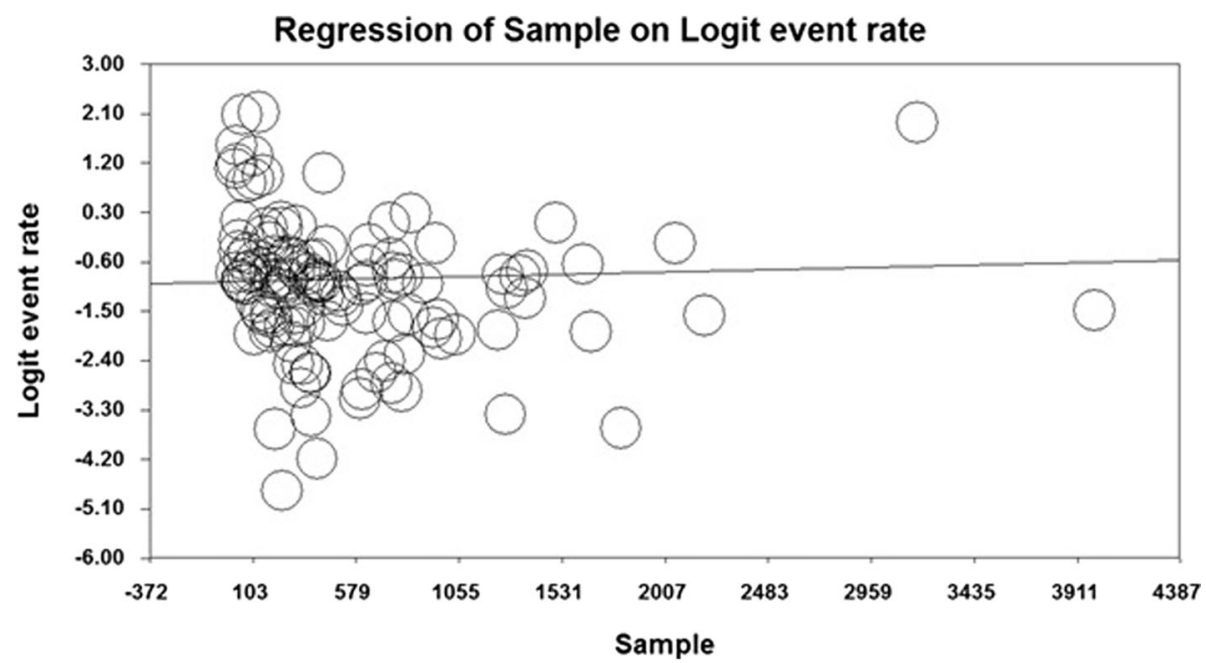

Figure 9. Meta-regression of prevalence of toxoplasmosis in cattle, sheep, camels, goats, and poultry worldwide based on sample size.

and will increase with the growing world population, our findings can be useful for policymakers to control toxoplasmosis in livestock.

\section{ACKNOWLEDGEMENTS}

This research was done by Research Center of Food Hygiene and Safety, Shahid Sadoughi University of Medical Sciences, Yazd, Iran (ID. No. 6808). We sincerely thank the technical supports of the staff of Research Center of Food Hygiene and Safety, Shahid Sadoughi University of Medical Sciences, Yazd, Iran.

\section{DeClarations}

CONFLICT OF INTEREST The authors declare that there is no conflict of interest regarding the publication of this paper.

ETHICAL APPROVAL In ethical approval was not required for this meta-analysis because no human or animal subjects were involved.

\section{REFERENCES}

Abdel-Hafeez E, Kamal A, Abdelgelil N, Abdel-Fatah M (2015) Parasites transmitted to human by ingestion of different types of meat, EL-Minia city, EL-Minia governorate, Egypt. Journal of the Egyptian Society of Parasitology 45:671-680. https://doi.org/ $10.12816 / 0017935$
Abdel-Rahman M, El-Manyawe SM, Khateib AM, Saba S (2012) Occurrence of Toxoplasma antibodies in caprine milk and serum in Egypt. Assiut Veterinary Medical Journal 58:145-152

Aboelhadid SM, Abdel-Ghany AE, Ibrahim MA, Mahran HA (2013) Seroprevalence of Toxoplasma gondii infection in chickens and humans in Beni Suef, Eygpt. Global Veterinaria 11:139-144. https://doi.org/10.5829/idosi.gv.2013.11.2.74193

Aguirre AA, Longcore T, Barbieri M, Dabritz H, Hill D, Klein PN, Lepczyk C, Lilly E, Mcleod R, Milcarsky J, Murphy CE, Su C, VanWormer E, Yolken R, Sizemore GC (2019) The one health approach to toxoplasmosis: epidemiology, control, and prevention strategies. EcoHealth 16:378-390. https://doi.org/ 10.1007/s10393-019-01405-7

Ahmad N, Qayyum M (2014) Seroprevalence and risk factors for toxoplasmosis in large ruminants in northern Punjab, Pakistan. Journal of Infection in Developing Countries 8:1022-1028. https:// doi.org/10.3855/jidc.4405

Ahmed NE, Al-Akabway LM, Ramadan MY, Abd El-Gawad SM, Moustafa MMA (2017) Serological and PCR-sequencing assays for diagnosis of Toxoplasma gondii and Neospora caninum infecting camels in Egypt. Benha Veterinary Medical Journal 33:200-210. https://doi.org/10.21608/BVMJ.2017.30466

Akhoundi S, Youssefi M (2017) Seroprevalence of sheep toxoplasmosis in north of Iran. Trakia Journal of Science 15:79-82. https://doi.org/10.15547/tjs.2017.01.013

Akhtar M, Ahmed AA, Awais MM, Saleemi MK, Ashraf K, Hiszczynska-Sawicka E (2014) Seroprevalence of Toxoplasma gondii in the Backyard chickens of the rural areas of Faisalabad Punjab Pakistan. International Journal of Agriculture and Biology 16:1105-1111

Aktas M, Dumanli N, Babur C, Karaer Z, Ongor H (2000) Determination of seropositivity for Toxoplasma gondii infection in pregnant and aborted sheep in Elazig and vicinity by SabinFeldman (SF) Test. Turkish Journal of Veterinary and Animal Sciences 24:239-241

Alanazi AD (2013) Determination of seropositivity for Toxoplasma gondii in sheep, goats and camels slaughtered for food and human consumptions in Riyadh municipal abattoirs, Saudi Arabia. Journal of the Egyptian Society of Parasitology 43:569576. https://doi.org/10.12816/0006414 
Al-Dabagh II, Jasim BM, Jarjees MT (2014) Seroprevalence of antibodies to toxoplasmosis, brucellosis and chlamydiosis in abortive sheep in Nineveh governorate, Iraq. Iraqi Journal of Veterinary Sciences 28:21-25

Al-Kappany YM, Abbas IE, Devleesschauwer B, Dorny P, Jennes M, Cox E (2018) Seroprevalence of anti-Toxoplasma gondii antibodies in Egyptian sheep and goats. BMC Veterinary Research 14:120. https://doi.org/10.1186/s12917-018-1440-1

Al-Ramahi HM, Hamza RH, Abdulla MA (2010) Seroprevalence study of toxoplasmosis in domestic animals in Mid-Euphrates region-Iraq. Journal of University of Babylon 18:1382-1387

Alvarado-Esquivel C, Estrada-Malacón MA, Reyes-Hernández SO, Pérez-Ramírez J, Trujillo-López J, Villena I, Dubey JP (2013) Seroprevalence of Toxoplasma gondii in domestic sheep in Oaxaca State, Mexico. The Journal of Parasitology 99:151-152. https://doi.org/10.1645/GE-3220.1

Alvarado-Esquivel C, Silva-Aguilar D, Villena I, Dubey J (2013) Seroprevalence of Toxoplasma gondii infection in dairy goats in Michoacán State, Mexico. The Journal of Parasitology 99:540542. https://doi.org/10.1645/12-103.1

Anwar S, Mahdy E, El-Nesr KA, El-Dakhly KM, Shalaby A, Yanai $\mathrm{T}$ (2013) Monitoring of parasitic cysts in the brains of a flock of sheep in Egypt. Revista Brasileira De Parasitologia Veterinária 22:323-330. https://doi.org/10.1590/S1984-29612013000300002

Amairia S, Rouatbi M, Rjeibi MR, Nouasri H, Sassi L, Mhadhbi M, Gharbi M (2016) Molecular prevalence of Toxoplasma gondii DNA in goats' milk and seroprevalence in Northwest Tunisia. Veterinary Medicine and Science 2:154-160. https://doi.org/ 10.1002/vms3.29

Amdouni Y, Rjeibi M, Rouatbi M, Amairia S, Awadi S, Gharbi M (2017) Molecular detection of Toxoplasma gondii infection in slaughtered ruminants (sheep, goats and cattle) in Northwest Tunisia. Meat Science 133:180-184. https://doi.org/10.1016/ j.meatsci.2017.07.004

Armand B, Solhjoo K, Shabani-Kordshooli M, Davami MH, Sadeghi M (2016) Toxoplasma infection in sheep from south of Iran monitored by serological and molecular methods; risk assessment to meat consumers. Veterinary World 9:850-855. https://doi.org/10.14202/vetworld.2016.850-855

Asgari Q, Farzaneh A, Kalantari M, Akrami Mohajeri F, Moazeni M, Zarifi M, Esmaeilzadeh B, Motazedian MH (2006) Seroprevalence of free-Ranging chicken toxoplasmosis in sub-urban regions of Shiraz, Iran. International Journal of Poultry Science 5:262-264. https://doi.org/10.3923/ijps.2006.262.264

Asgari Q, Mehrabani D, Moazzeni M, Akrami-Mohajeri F, Kalantari M, Motazedian M, Hatam GR (2009) The seroprevalence of ovine toxoplasmosis in Fars Province, Southern Iran. Asian Journal of Animal Veterinary Advances 4:332-336. https://doi.org/10.3923/ajava.2009.332.336

Asgari Q, Motazedian MH, Esmaeelzadeh B, Kalantari M, Hatam $\mathrm{G}$ (2009) The prevalence of toxoplasma infection among freeranging chickens in Southern Iran using IFA and nested-PCR. Iranian Journal of Parasitology 4:29-36

Asgari Q, Sarnevesht J, Kalantari M, Adnani Sadat SJ, Motazedian MH, Sarkari B (2011) Molecular survey of Toxoplasma infection in sheep and goat from Fars province, Southern Iran. Tropical Animal Health and Production 43:389-392. https://doi.org/ 10.1007/s11250-010-9704-1

Atail HB, Ibrahaem HH, Shuaib YA, Mohamed AK, Suliman SE, Idris SH, Abdalla MA (2017) Sero-prevalence of toxoplasmosis in sheep and goats in El-Gadarif state. Journal of Advanced
Veterinary and Animal Research 4:207-213. https://doi.org/ 10.5455/javar.2017.d205

Ayinmode AB, Abiola JO (2016) Investigating potential sources of toxoplasmosis for humans from slaughtered food animals in Ibadan, Nigeria. Folia Veterinaria 60:34-40. https://doi.org/ 10.1515/FV-2016-0016

Azizi HR, Shiran B, Borjian Boroujeni A, Jafari M (2014) Molecular survey of Toxoplasma gondii in sheep, cattle and meat products in Chaharmahal va Bakhtiari Province, Southwest of Iran. Iranian Journal of Parasitology 9:429-434

Bachan M, Deb AR, Maharana BR, Sudhakar NR, Sudan V, Saravanan BC, Tewari AK (2018) High seroprevalence of Toxoplasma gondii in goats in Jharkhand state of India. Veterinary Parasitology, Regional Studies and Reports 12:61-68. https:// doi.org/10.1016/j.vprsr.2018.02.004

Balea A, Paştiu AI, Györke A, Mircean V, Cozma V (2012) The dynamics of anti-Toxoplasma gondii antibodies (IgG) in small ruminants and pigs from Cluj County, Romania. Science Parasitology 13:163-168

Bawm S, Maung WY, Win MY, Thu MJ, Chel HM, Khaing TA, Wai SS, Htun LL, Myaing TT, Tiwananthagorn S, Igarashi M, Katakura K (2016) Serological survey and factors associated with Toxoplasma gondii infection in domestic goats in Myanmar. Scientifica (cairo) 2016:4794318. https://doi.org/10.1155/ 2016/4794318

Begg CB, Mazumdar M (1994) Operating characteristics of a rank correlation test for publication bias. Biometrics 50:1088-1101

Boughattas S (2017) Toxoplasma infection and milk consumption: meta-analysis of assumptions and evidences. Critical Reviews in Food Science and Nutrition 57:2924-2933. https:// doi.org/10.1080/10408398.2015.1084993

Boughattas S, Bouratbine A (2014) Prevalence of food-borne Toxoplasma gondii in free-ranging chickens sold in Tunis, Tunisia. Journal of Food Quality and Hazards Control 1:89-92

Boughattas S, Bouratbine A (2015) Genetic characterization of Toxoplasma gondii isolated from chicken meats in Tunisia. Journal of Food Quality and Hazards Control 2:97-100

Celik OY, Ipek DNS, Celik BA, Irak K, Akgul G (2018) Investigation of seroprevalence of Toxoplasma gondii in cattle in Siirt province in Turkey. Indian Journal of Animal Research 52:10531057. https://doi.org/10.18805/ijar.B-827

Cenci-Goga BT, Ciampelli A, Sechi P, Veronesi F, Moretta I, Cambiotti V, Thompson PN (2013) Seroprevalence and risk factors for Toxoplasma gondii in sheep in Grosseto district, Tuscany, Italy. BMC Veterinary Research 9:25

Chikweto A, Kumthekar S, Tiwari K, Nyack B, Deokar MS, Stratton G, Macpherson CNL, Sharma RN, Dubey JP (2011) Seroprevalence of Toxoplasma gondii in pigs, sheep, goats, and cattle from Grenada and Carriacou, West Indies. The Journal of Parasitology 97:950-951. https://doi.org/10.1645/GE-2811.1

Dalir Ghaffari A, Dalimi A (2019) Molecular Identification of Toxoplasma gondii in the Native Slaughtered Cattle of Tehran Province, Iran. Journal of Food Quality and Hazards Control 6:153-161. https://doi.org/10.18502/jfqhc.6.4.1993

Da Silva AS, Tonin AA, Camillo G, Weber A, Lopes LS, Cazarotto CJ, Balzan A, Bianchi AE, Stefani LM, Lopes STA, Vogel FF (2014) Ovine toxoplasmosis: Indirect immunofluorescence for milk samples as a diagnostic tool. Small Ruminant Research 120:181-184. https://doi.org/10.1016/j.smallrumres.2014.03.013

Davoust B, Mediannikov O, Roqueplo C, Perret C, Demoncheaux JP, Sambou M, Guillot J, Blaga R (2015) Serological survey of animal toxoplasmosis in Senegal. Bulletin De La Société De 
Pathologie Exotique 108:73-77. https://doi.org/10.1007/s13149014-0403-4

De Berardinis A, Paludi D, Pennisi L, Vergara A (2017) Toxoplasma gondii, a foodborne pathogen in the swine production chain from a European Perspective. Foodborne Pathogens Disease 14:637-648. https://doi.org/10.1089/fpd.2017.2305

Dechicha AS, Bachi F, Gharbi I, Gourbdji E, Baazize-Ammi D, Guetarni D (2015) Sero-epidemiological survey on toxoplasmosis in cattle, sheep and goats in Algeria. African Journal of Agricultural Research 10:2113-2119. https://doi.org/10.5897/ AJAR2015.9575

Deng H, Dam-Deisz C, Luttikholt S, Maas M, Nielen M, Swart A, Vellema P, van der Giessen J, Opsteegh M (2016) Risk factors related to Toxoplasma gondii seroprevalence in indoor-housed Dutch dairy goats. Preventive Veterinary Medicine 124:45-51. https://doi.org/10.1016/j.prevetmed.2015.12.014

Diakoua A, Papadopoulos E, Panousis N, Karatzias C, Giadinis N (2013) Toxoplasma gondii and Neospora caninum seroprevalence in dairy sheep and goats mixed stock farming. Veterinary Parasitology 198:387-390. https://doi.org/10.1016/j.vetpar.2013.09.017

Djokic V, Klun I, Musella V, Rinaldi L, Cringoli G, Sotiraki S, Djakovic OD (2014) Spatial epidemiology of Toxoplasma gondii infection in goats in Serbia. Geospatial Health 8:479-488. https://doi.org/10.4081/gh.2014.37

Dong H, Su R, Lu Y, Wang M, Liu J, Jian F, Yang Y (2018) Prevalence, risk factors, and genotypes of Toxoplasma gondii in food animals and humans (2000-2017) from China. Frontiers in Microbiology 9:1-10. https://doi.org/10.3389/fmicb.2018.02108

Dubey JP, Graham DH, Blackston CR, Lehmann T, Gennari SM, Ragozo AM, Nishi SM, Kwok OC, Hill DE, Thulliez P (2002) Biological and genetic characterisation of Toxoplasma gondii isolates from chickens (Gallus domesticus) from São Paulo, Brazil: unexpected findings. International Journal for Parasitology 32:99-105. https://doi.org/10.1016/s0020-7519(01)00364-2

Dubey JP, Graham DH, Dahl E, Hilali M, El-Ghaysh A, SreekumarC Kwok OCH, Shen SK, Lehmann T (2003) Isolation and molecular characterization of Toxoplasma gondii from chickens and ducks from Egypt. Veterinary Parasitology 114:89-95. https://doi.org/10.1016/s0304-4017(03)00133-x

Dubey JP, Jones JL (2008) Toxoplasma gondii infection in humans and animals in the United States. International Journal for Parasitology 38:1257-1278. https://doi.org/10.1016/j.ijpara.2008.03.007

Dubey JP, Levy MZ, Sreekumar C, Kwok OCH, Shen SK, Dahl E, Thulliez P, Lehmann T (2004) Tissue distribution and molecular characterization of chicken isolates of Toxoplasma gondii from Peru. The Journal of Parasitology 90:1015-1018. https:// doi.org/10.1645/GE-329R

Dubey JP, Lindsay DS, Speer CA (1998) Structures of Toxoplasma gondii tachyzoites, bradyzoites, and sporozoites and biology and development of tissue cysts. Clinical Microbiology Review 11:267-299

Dubey JP, Navarro IT, Graham DH, Dahl E, Freire RL, Prudencio LB, Sreekumar C, Vianna MC, Lehmann T (2003) Characterization of Toxoplasma gondii isolates from free range chickens from Paraná, Brazil. Veterinary Parasitology 117:229-234. https://doi.org/10.1016/j.vetpar.2003.09.003

Dubey JP, Rajendran C, Ferreira LR, Martins J, Kwok OCH, Hill DE, Villena I, Zhou H, Su C, Jones JL (2011) High prevalence and genotypes of Toxoplasma gondii isolated from goats, from a retail meat store, destined for human consumption in the USA.
International Journal for Parasitology 41:827-833. https:// doi.org/10.1016/j.ijpara.2011.03.006

Dubey JP, Sundar N, Hill D, Velmurugan GV, Bandini LA, Kwok OCH, Majumdar D, Su C (2008) High prevalence and abundant atypical genotypes of Toxoplasma gondii isolated from lambs destined for human consumption in the USA. International Journal for Parasitology 38:999-1006. https://doi.org/10.1016/ j.ijpara.2007.11.012

Egger M, Davey Smith G, Schneider M, Minder C (1997) Bias in meta-analysis detected by a simple, graphical test. British Medical Journal 13:629-634. https://doi.org/10.1136/ bmj.315.7109.629

Elfahal AM, Elhassan AM, Hussien MO, Enan KA, Musa AB, El Hussein AM (2013) Seroprevalence of Toxoplasma gondii in dairy cattle with reproductive problems in Sudan. International Scholarly Research Notices . https://doi.org/10.1155/2013/895165

El-Massry A, MahdyOA El-Ghaysh A, Dubey JP (2000) Prevalence of Toxoplasma gondii antibodies in sera of turkeys, chickens, and ducks from Egypt. Journal of Parasitology 86:627-628

Fereig RM, Mahmoud HYAH, Mohamed SGA, Mohamed AEA, Nishikawa Y (2016) Seroprevalence and epidemiology of Toxoplasma gondii in farm animals in different regions of Egypt. Veterinary Parasitology: Regional Studies and Reports 3-4:1-6. https://doi.org/10.1016/j.vprsr.2016.05.002

Figliuolo LPC, Rodrigues AAR, Viana RB, Aguiar DM, Kasai N, Gennari SM (2004) Prevalence of anti-Toxoplasma gondii and anti-Neospora caninum antibodies in goat from São Paulo State, Brazil. Small Ruminant Research 55:29-32. https://doi.org/ 10.1016/j.smallrumres.2003.12.013

Foroutan M, Fakhri Y, Riahi SM, Ebrahimpour S, Namroodi S, Taghipour A, Spotin A, Gamble HR, Rostami A (2019) The global seroprevalence of Toxoplasma gondii in pigs: a systematic review and meta-analysis. Veterinary Parasitology 269:42-52. https://doi.org/10.1016/j.vetpar.2019.04.012

Franco-Hernandez EN, Acosta A, Cortés-Vecino J, Gómez-Marín JE (2016) Survey for Toxoplasma gondii by PCR detection in meat for human consumption in Colombia. Parasitology Research 115:691-695. https://doi.org/10.1007/s00436-015-4790-7

Frazão-Teixeira E, de Oliveira FCR (2011) Anti-Toxoplasma gondii antibodies in cattle and pigs in a highly endemic area for human toxoplasmosis in Brazil. The Journal of Parasitology 97:44-47. https://doi.org/10.1645/GE-2457.1

García-Bocanegra I, Cábezón O, Hernández E, Martínez-Cruz MS, Martínez-Moreno Á, Martínez-Moreno J (2013) Toxoplasma gondii in ruminant species (cattle, sheep, and goats) from southern Spain. The Journal of Parasitology 99:438-440. https:// doi.org/10.1645/12-27.1

Gebremedhin EZ, Abdurahaman M, Hadush T, Tessema TS (2014) Seroprevalence and risk factors of Toxoplasma gondii infection in sheep and goats slaughtered for human consumption in Central Ethiopia. BMC Research Notes 7:696. https:// doi.org/10.1186/1756-0500-7-696

Gebremedhin EZ, Agonafir A, Tessema TS, Tilahun G, Medhin G, Vitale M, Di Marco V (2013) Some risk factors for reproductive failures and contribution of Toxoplasma gondii infection in sheep and goats of Central Ethiopia: a cross-sectional study. Research in Veterinary Science 95:894-900. https://doi.org/ 10.1016/j.rvsc.2013.08.007

Gebremedhin EZ, Gizaw D (2014) Seroprevalence of Toxoplasma gondii infection in sheep and goats in three districts of Southern Nations, nationalities and peoples' region of Ethiopia. World 
Applied Sciences Journal 31:1891-1896. https://doi.org/10.5829/ idosi.wasj.2014.31.11.83312

Gebreyes WA, Bahnson PB, Funk JA, McKean J, Patchanee P (2008) Seroprevalence of Trichinella, Toxoplasma, and Salmonella in antimicrobial-free and conventional swine production systems. Foodborne Pathogens and Disease 5:199-203. https://doi.org/10.1089/fpd.2007.0071

Ge W, Sun H, Wang Z, Xu P, Wang W, Mu G, Wei F, Liu Q (2014) Prevalence and genotype of Toxoplasma gondii infection in cattle from Jilin Province, northeastern China. Vector Borne and Zoonotic Diseases (larchmont, NY) 14:399-402. https:// doi.org/10.1089/vbz.2013.1516

Ghazaei C (2006) Serological survey of antibodies to Toxoplasma gondii. African Journal of Health Sciences 13:131-134

Giangaspero M, Bonfini B, Orusa R, Savini G, Osawa T, Harasawa $\mathrm{R}$ (2013) Epidemiological survey for Toxoplasma gondii, Chlamydia psittaci var. ovis, Mycobacterium paratuberculosis, Coxiella burnetii, Brucella spp., leptospirosis and Orf virus among sheep from northern districts of Japan. The Journal of Veterinary Medical Science 75:679-684. https://doi.org/10.1292/jvms.120384

Gorji GRS, Rassouli M, Staji H (2018) Prevalence of cerebral toxoplasmosis among slaughtered sheep in Semnan, Iran. Annals of Parasitology 64:37-42. https://doi.org/10.17420/ ap6401.130

Guimarães LA, Bezerra RA, Rocha DS, Albuquerque GR (2013) Prevalence and risk factors associated with anti-Toxoplasma gondii antibodies in sheep from Bahia state, Brazil. The Revista Brasileira De Parasitologia Veterinária 22:220-224. https:// doi.org/10.1590/S1984-29612013000200041

Hamidinejat H, Ghorbanpour M, Nabavi L, Haji Hajikolaei MR, Razi Jalali MH (2009) Occurrence of anti-Toxoplasma gondii antibodies in female cattle in south-west of Iran. Tropical Animal Health and Production 42:899-903. https://doi.org/10.1007/ s11250-009-9505-6

Hamidinejat H, Ghorbanpour M, Rasooli A, Nouri M, Hekmatimoghaddam SH, Namavari M, Pourmahdi M, Sazmand AR (2013) Occurrence of anti-Toxoplasma gondii and Neospora caninum antibodies in camels (Camelus dromedarius) in the center of Iran. Turkish Journal of Veterinary and Animal Sciences 37:277-281. https://doi.org/10.3906/vet-1110-21

Hamidinejat H, Goraninejad S, Ghorbanpoor M, Nabavi L, Akbarnejad F (2008) Role of Toxoplasma gondii in abortion of ewes in Ahvaz (South-West Iran). Bulletin of the Veterinary Institute in Pulawy 52:369-371

Hammond-Aryee K, Van Helden LS, Van Helden PD (2015) The prevalence of antibodies to Toxoplasma gondii in sheep in the Western Cape, South Africa. Onderstepoort. Journal of Advanced Veterinary and Animal Research 82:993. https://doi.org/ 10.4102/ojvr.v82i1.993

Havakhah Y, Esmaeili Rastaghi AR, Amiri S, Babaie J, Aghighi Z, Golkar M (2014) Prevalence of Toxoplasma gondii in sheep and goats in three counties of Gilan Province, North of Iran the more humid climate the higher prevalence. Journal of Medical Microbiology and Infectious Diseases 2:80-83

Hill DE, Dubey JP (2013) Toxoplasma gondii prevalence in farm animals in the United States. International Journal of Parasitology 43:107-113. https://doi.org/10.1016/j.ijpara.2012.09.012

Holec-Gasior L, Drapala D, Dominiak-Gorski B, Kur J (2013) Epidemiological study of Toxoplasma gondii infection among cattle in Northern Poland. Annals of Agricultural and Environmental Medicine 20:653-656
Hotez PJ (2014) Neglected parasitic infections and poverty in the United States. PLoS Neglected Tropical Diseases 8:e3012. https:// doi.org/10.1371/journal.pntd.0003012

Ibrahim HM, Abdel-Ghaffar F, Osman GY, El-Shourbagy SH, Nishikawa Y, Khattab RA (2016) Prevalence of Toxoplasma gondii in chicken samples from delta of Egypt using ELISA, histopathology and immunohistochemistry. Journal of Parasitic Diseases 40:485-490. https://doi.org/10.1007/s12639-014-0530-7

Ibrahim A, Ismail AA, Elkhansa T, Angara TEE (2014) Serological Survey on Toxoplasma gondii in Dairy Cows from the Sudan using ELISA. Global Journal of Animal Sceinces, Livestock Production and Animal Breeding 2:114-118

Ibrahim HM, Mohamed AH, El-Sharaawy AA, El-Shqanqery HE (2017) Molecular and serological prevalence of Toxoplasma gondii in pregnant women and sheep in Egypt. Asian Pacific Journal of Tropical Medicine 10:996-1001. https://doi.org/ 10.1016/j.apjtm.2017.09.012

Ichikawa-Seki M, Guswanto A, Allamanda P, Mariamah ES, Wibowo PE, Igarashi I, Nishikawa Y (2015) Seroprevalence of antibody to TgGRA7 antigen of Toxoplasma gondii in livestock animals from Western Java, Indonesia. Parasitology International 64:484-486. https://doi.org/10.1016/j.parint.2015.07.004

Iovu A, Györke A, Mircean V, Gavrea R, Cozma V (2012) Seroprevalence of Toxoplasma gondii and Neospora caninum in dairy goats from Romania. Veterinary ParasitoLogy 186:470-474. https://doi.org/10.1016/j.vetpar.2011.11.062

Jittapalapong S, Sangvaranond A, Pinyopanuwat N, Chimnoi W, Khachaeram W, Koizumi S, Maruyama S (2005) Seroprevalence of Toxoplasma gondii infection in domestic goats in Satun Province, Thailand. Veterinary Parasitology 127:17-22. https:// doi.org/10.1016/j.vetpar.2004.08.019

Jung BY, Gebeyehu EB, Lee SH, Seo MG, Byun JW, Oem JK, Kim HY, Kwak D (2014) Detection and determination of Toxoplasma gondii seroprevalence in native Korean goats (Capra hircus coreanae). Vector Borne and Zoonotic Diseases (larchmont, NY) 14:374-377. https://doi.org/10.1089/vbz.2013.1452

Kalambhe D, Gill JPS, Singh BB (2017) Molecular detection of Toxoplasma gondii in the slaughter sheep and goats from North India. Veterinary Parasitology 241:35-38. https://doi.org/ 10.1016/j.vetpar.2017.05.009

Kamani J, Mani A, Egwu GO (2009) Seroprevalence of Toxoplasma gondii infection in domestic sheep and goats in Borno state, Nigeria. Tropical Animal Health and Production 42:793797. https://doi.org/10.1007/s11250-009-9488-3

Kavari A, Nowzari N, Moazeni Jula G, Moazeni Jula F, Hashemzadeh H (2013) A serological and molecular study on Toxoplasma gondii infection in sheep and goat in Tabriz. Archives of Razi Institute 68:29-35. https://doi.org/10.7508/ ARI.2013.01.005

Khalil KM, Elrayah IE (2011) Seroprevalence of Toxoplasma gondii antibodies in farm animals (camels, cattle, and sheep) in Sudan. Journal of Veterinary Medicine and Animal Health 3:36-39

Khamesipour F, Doosti A, Iranpour Mobarakeh H, Komba EV (2014) Toxoplasma gondii in cattle, camels and sheep in Isfahan and Chaharmahal va Bakhtiary Provinces, Iran. Jundishapur Journal of Microbiology 7:e17460. https://doi.org/10.5812/ jjm. 17460

Khlaty AH, Naji N (2015) Molecular and serological detection of T. gondii in sheep in Wasit province. Al-Qadisiyah Journal of Veterinary Medicine Sciences 14:34-42

Koethe M, Schade C, Fehlhaber K, Ludewig M (2017) Survival of Toxoplasma gondii tachyzoites in simulated gastric fluid and 
cow milk. Veterinary Parasitology 233:111-114. https://doi.org/ 10.1016/j.vetpar.2016.12.010

Kuraa HM, Malek SS (2016) Seroprevalence of Toxoplasma gondii in ruminants by using latex agglutination test (LAT) and enzyme-linked immunosorbent assay (ELISA) in Assiut governorate. Tropical Biomedicine 33:711-725

Kyan H, Taira M, Yamamoto A, Inaba C, Zakimi S (2012) Isolation and characterization of Toxoplasma gondii genotypes from goats at an abattoir in Okinawa. Japanese Journal of Infectious Diseases 65:167-170

Lahmar I, Lachkhem A, Slama D, Sakly W, Haouas N, Gorcii M, Pfaff W, A,Candolfi E, Babba H, (2015) Prevalence of toxoplasmosis in sheep, goats and cattle in Southern Tunisia. Journal of Bacteriology \& Parasitology 6:1000245. https://doi.org/ 10.4172/2155-9597.1000245

Lashari MH, Tasawar Z (2010) Seroprevalence of toxoplasmosis in sheep in Southern Punjab. Pakistan Veterinary Journal 30:91-94

Lazim SAM, Ibrahim AM, Ahmed AB (2018) Seroprevalence of Toxoplasma Gondii in cattle, sheep and goats from River Nile State, Sudan. Multidisciplinary Advances in Veterinary Science $2: 332-337$

Lopes AP, Vilares A, Francisco N, Rodrigues A, Martins T, Ferreira I, Gargate MJ, Rodrigues M, Cardoso L (2015) Genotyping characterization of Toxoplasma gondii in cattle, sheep, goats and swine from the north of Portugal. Iranian Journal of Parasitology 10:465-472

Lopes CS, Franco PS, Silva NM, Silva DAO, Ferro EAV, Pena HFJ, Soares RM, Gennari SM, Mineo JR (2016) Phenotypic and genotypic characterization of two Toxoplasma gondii isolates in free-range chickens from Uberlândia, Brazil. Epidemiology and Infection 144:1865-1875. https://doi.org/10.1017/ S0950268815003295

Lorencová A, Lamka J, Reslová N, Škorpíková L, Slaný M (2016) The meat of goat kids and lambs as a possible source of Toxoplasma gondii for consumers. Maso International, Veterinární a Farmaceutická Univerzita Brno 1:19-23

Luo H, Li K, Zhang H, Gan P, Shahzad M, Wu X, Lan Y, Wang J (2017) Seroprevalence of Toxoplasma gondii infection in zoo and domestic animals in Jiangxi Province, China. Parasite 24:7. https://doi.org/10.1051/parasite/2017007

Luptakova L, Benova K, Rencko A, Petrovova E (2015) DNA detection of Toxoplasma gondii in sheep milk and blood samples in relation to phase of infection. Veterinary Parasitology 208:250-253. https://doi.org/10.1016/j.vetpar.2014.12.002

Mahami-Oskouei M, Moradi M, Fallah E, Hamidi F, Akbari N (2017) Molecular detection and genotyping of Toxoplasma gondii in chicken, beef, and lamb meat consumed in northwestern Iran. Iranian Journal of Parasitology 12:38-45

Mammari N, Halabi MA, Yaacoub S, Chlala H, Darde ML, Courtioux B (2019) Toxoplasma gondii modulates the host cell responses: an overview of apoptosis pathways. Biomed Research International 2019:6152489. https://doi.org/10.1155/2019/ 6152489

Matsuo K, Kamai R, Uetsu H, Goto H, Takashima Y, Nagamune $\mathrm{K}$ (2014) Seroprevalence of Toxoplasma gondii infection in cattle, horses, pigs and chickens in Japan. Parasitology International 63:638-639. https://doi.org/10.1016/j.parint.2014.04.003

Mišurová Ľ, Svobodová V, Pavlata L, Dvořák R (2009) Titres of specific antibodies against Toxoplasma gondii in goats and their kids. Acta Veterinaria Brno 78:259-266. https://doi.org/10.2754/ avb200978020259
Moher D, Liberati A, Tetzlaff J, Altman DGThe PRISMA Group (2009) Preferred reporting items for systematic reviews and meta-analyses: the PRISMA statement. PLoS Medicine 21:e1000097. https://doi.org/10.1371/journal.pmed.1000097

Moraes LM, Raimundo JM, Guimarães A, Santos HA, GdeL Macedo Junior, Massard CL, Machado RZ, Baldani CD (2011) Occurrence of anti-Neospora caninum and anti-Toxoplasma gondii IgG antibodies in goats and sheep in western Maranhão, Brazil. Revista Brasileira De Parasitologia Veterinaria 20:312317. https://doi.org/10.1590/s1984-29612011000400010

Morley EK, Williams RH, Hughes JM, Thomasson D, Terry RS, Duncanson P, Smith JE, Hide G (2008) Evidence that primary infection of Charollais sheep with Toxoplasma gondii may not prevent foetal infection and abortion in subsequent lambings. Parasitology 135:169-173. https://doi.org/10.1017/ S0031182007003721

Mosallanejad B, Avizeh R, Razi Jalali MH, Pourmehdi M (2011) A study on seroprevalence and coproantigen detection of Toxoplasma gondii in companion cats in Ahvaz area, southwestern Iran. Iranian Journal of Veterinary Research 12:139-144

Mose JM, Kagira JM, Karanja SM, Ngotho M, Kamau DM, Njuguna AN (2016) Detection of natural Toxoplasma gondii infection in chicken in Thika Region of Kenya using nested polymerase chain reaction. BioMed Research International 2016:7589278. https://doi.org/10.1155/2016/7589278

Moskwa B, Kornacka A, Cybulska A, Cabaj W, Reiterova K, Bogdaszewski M, Steiner-Bogdaszewska Z, Bien J (2018) Seroprevalence of Toxoplasma gondii and Neospora caninum infection in sheep, goats, and fallow deer farmed on the same area. Journal of Animal Science 96:2468-2473. https://doi.org/ 10.1093/jas/sky122

Neto JO, Azevedo SS, Gennari SM, Funada MR, Pena HF, Araújo AR, Batista CS, Silva ML, Gomes AA, Piatti RM, Alves CJ (2008) Prevalence and risk factors for anti-Toxoplasma gondii antibodies in goats of the Seridó Oriental microregion, Rio Grande do Norte state, Northeast region of Brazil. Veterinary Parasitology 156:329-332. https://doi.org/10.1016/j.vetpar.2008.05.013

Olfaty-Harsini S, Shokrani H, Nayebzadeh H (2017) Toxoplasma gondii infection in slaughtered ewes in Khorramabad, west of Iran: A preliminary molecular study. Iranian Journal of Veterinary Medicine 11:209-215. https://doi.org/10.22059/ IJVM.2017.222331.1004780

Oncel T, Vural G (2006) Occurrence of Toxoplasma gondii antibodies in sheep in Istanbul, Turkey. Veterinarski Arhiv 76:547553

Onyiche TGE, Ademola IO (2015) Seroprevalence of anti-Toxoplasma gondii antibodies in cattle and pigs in Ibadan, Nigeria. Journal of Parasitic Diseases 39:309-314. https://doi.org/10.1007/ s12639-013-0350-1

Persad A, Charles R, Adesiyun AA (2011) Frequency of toxoplasmosis in water buffalo (Bubalus bubalis) in Trinidad. Veterinary Medicine International 2011:705358. https://doi.org/ $10.4061 / 2011 / 705358$

Qiu JH, Wang CR, Zhang X, Sheng ZH, Chang QC, Zhao Q, Wu SM, Zou FC, Zhu XQ (2012) Seroprevalence of Toxoplasma gondii in beef cattle and dairy cattle in northeast China. Foodborne Pathogens and Disease 9:579-582. https://doi.org/10.1089/ fpd.2011.1104

Rahimi MT, Daryani A, Sarvi S, Shokri A, Ahmadpour E, Teshnizi SH, Mizani A, Sharif M (2015) Cats and Toxoplasma gondii: a systematic review and meta-analysis in Iran. Onderstepoort 
Journal of Veterinary Research 82:e1-e10. https://doi.org/ 10.4102/ojvr.v82i1.823

Razmi GR, Ghezi K, Mahooti A, Naseri Z (2010) A serological study and subsequent isolation of Toxoplasma gondii from aborted ovine fetuses in Mashhad area, Iran. The Journal of Parasitology 96:812-814. https://doi.org/10.1645/ge-2428.1

Robert-Gangneux F, Darde ML (2012) Epidemiology of and diagnostic strategies for toxoplasmosis. Clinical Microbiology Reviews 25:264-296. https://doi.org/10.1128/CMR.05013-11

Romanelli PR, Freire RL, Vidotto O, Marana ERM, Ogawa L, De Paula VSO, Garcia JL, Navarro IT (2007) Prevalence of Neospora caninum and Toxoplasma gondii in sheep and dogs from Guarapuava farms, Paraná State, Brazil. Research in Veterinary Science 82:202-207. https://doi.org/10.1016/j.rvsc.2006.04.001

Roqueplo C, Halos L, Cabre O, Davoust B (2011) Toxoplasma gondii in wild and domestic animals from New Caledonia. Parasite 18:345-348. https://doi.org/10.1051/parasite/ 2011184345

Rostami A, Riahi SM, Fakhri Y, Saber V, Hanifehpour H, Valizadeh S, Gholizadeh M, Hosseini Pouya R, Gamble HR (2017) The global seroprevalence of Toxoplasma gondii among wild boars: a systematic review and meta-analysis. Veterinary Parasitology 244:12-20. https://doi.org/10.1016/j.vetpar.2017.07.013

Rouatbi M, Amdouni Y, Amairia S, Rjeibi MR, Sammoudi S, Rekik M, Gharbi M (2017) Molecular detection and phylogenetic analyses of Toxoplasma gondii from naturally infected sheep in Northern and Central Tunisia. Veterinary Medicine and Science 3:22-31

Saad NM, Hussein AAA, Ewida RM (2018) Occurrence of Toxoplasma gondii in raw goat, sheep, and camel milk in Upper Egypt. Veterinary World 11:1262-1265. https://doi.org/ 10.14202/vetworld.2018.1262-1265

Safarpoor Dehkordi F, Haghighi Borujeni MR, Rahimi E, Abdizadeh R (2013) Detection of Toxoplasma gondii in raw caprine, ovine, buffalo, bovine, and camel milk using cell cultivation, cat bioassay, capture ELISA, and PCR methods in Iran. Foodborne Pathogens and Disease 10:120-125. https://doi.org/10.1089/ fpd.2012.1311

Samra NA, McCrindle C, Penzhorn B, Cenci-Goga B (2007) Seroprevalence of toxoplasmosis in sheep in South Africa. Journal of the South African Veterinary Association 78:116-120. https://doi.org/10.4102/jsava.v78i3.301

Sarkari B, Asgari Q, Bagherian N, Ashkani Esfahani S, Kalantari M, Mohammadpour I, Ashrafmansori M, Amerinia M, Sabet Sarvestani F (2014) Molecular and serological evaluation of toxoplasma gondii infection in reared turkeys in Fars Province, Iran. Jundishapur Journal of Microbiology 7:e11598. https:// doi.org/10.5812/jjm.11598

Sawadogo P, Hafid J, Bellete B, Sung RTM, Chakdi M, Flori P, Raberin H, Hamouni IB, Chait A, Dalal A (2005) Seroprevalence of T. gondii in sheep from Marrakech, Morocco. Veterinary Parasitology 130:89-92. https://doi.org/10.1016/ j.vetpar.2005.03.025

Sechi P, Ciampelli A, Cambiotti V, Veronesi F, Cenci-Goga BT (2013) Seroepidemiological study of toxoplasmosis in sheep in rural areas of the Grosseto district, Tuscany, Italy. Italian Journal of Animal Science 12:e39. https://doi.org/10.4081/ ijas.2013.e39

Shah M, Zahid M, Asmat P, Alam A, Sthanadar AA (2013) Seroprevalence of Toxoplasma gondii in goats and sheep of district Mardan, Pakistan. International Journal of Biosciences 7:90-97. https://doi.org/10.12692/ijb/3.7.90-97
Sharif M, Gholami SH, Ziaei H, Daryani A, Laktarashi B, Ziapour SP, Rafiei A, Vahedi M (2005) Seroprevalence of Toxoplasma gondii in cattle, sheep and goats slaughtered for food in Mazandaran province, Iran, during 2005. Veterinary Journal 174:422-424. https://doi.org/10.1016/j.tvjl.2006.07.004

Sharif M, Sarvi S, Shokri A, Hosseini Teshnizi S, Rahimi MT, Mizani A, Ahmadpour E, Daryani A (2015) Toxoplasma gondii infection among sheep and goats in Iran: a systematic review and meta-analysis. Parasitology Research 114:1-16. https:// doi.org/10.1007/s00436-014-4176-2

Sharma S, Sandhu KS, Bal MS, Kumar H, Verma S, Dubey JP (2008) Serological survey of antibodies to Toxoplasma gondii in sheep, cattle, and buffaloes in Punjab, India. The Journal of Parasitology 94:1174-1175. https://doi.org/10.1645/GE-1556.1

Singh H, Tewari AK, Mishra AK, Maharana B, Sudan V, Raina OK, Rao JR (2015) Detection of antibodies to Toxoplasma gondii in domesticated ruminants by recombinant truncated SAG2 enzyme-linked immunosorbent assay. Tropical Animal Health and Production 47:171-178. https://doi.org/10.1007/ s11250-014-0703-5

Sroka J, Kusyk P, Bilska-Zajac E, Karamon J, Dutkiewicz J, Wojcik-Fatla A, Zajac V, Stojecki K, Rozycki M, Cencek T (2017) Seroprevalence of Toxoplasma gondii infection in goats from the south-west region of Poland and the detection of $T$. gondii DNA in goat milk. Folia Parasitologica . https://doi.org/ 10.14411/fp.2017.023

Stelzer S, Basso W, Benavides Silván J, Ortega-Mora LM, Maksimov P, Gethmann J, Conraths FJ, Schares G (2019) Toxoplasma gondii infection and toxoplasmosis in farm animals: Risk factors and economic impact. Food and Waterborne Parasitology 15:e00037

Stormoen M, Tharaldsen J, Hopp P (2012) Seroprevalence of Toxoplasma gondii infection in Norwegian dairy goats. Acta Veterinaria Scandinavica 54:75. https://doi.org/10.1186/17510147-54-75

Sunanta C, Inpankaew T, Pinyopanuwat N, Chimnoi W, Kengradomkij C, Arunwipas P, Maruyama S, Jittapalapong S (2009) Comparison of diagnostic technique for detection of Toxoplasma gondii infection in dairy cows in Thailand. Kasetsart Journal, Natural Sciences 43:48-52

Swai ES, Kaaya JE (2012) A survey of Toxoplasma gondii antibodies by latex agglutination assay in dairy goats in Northern Tanzania. Tropical Animal Health and Production 45:211-217. https://doi.org/10.1007/s11250-012-0193-2

Tavakoli Kareshk A, Mahmoudvand H, Keyhani A, Tavakoli Oliaee R, Mohammadi MA, Babaei Z, Hajhosseini MA, Zia-Ali $\mathrm{N}$ (2017) Molecular detection and genetic diversity of Toxoplasma gondii in different tissues of sheep and goat in Eastern Iran. Tropical Biomedicine 34:681-690

Tavassoli M, Ghorbanzadehghan M, Esmaeilnejad B (2013) Detection of Toxoplasma gondii in sheep and goats blood samples by PCR-RFLP in Urmia. Veterinary Research Forum 4:43-47

Tilahun B, Tolossa YH, Tilahun G, Ashenafi H, Shimelis S (2018) Seroprevalence and risk factors of Toxoplasma gondii infection among domestic ruminants in East Hararghe Zone of Oromia Region, Ethiopia. Veterinary Medicine International 2018:4263470. https://doi.org/10.1155/2018/4263470

Torgerson PR, Mastroiacovo P (2013) The global burden of congenital toxoplasmosis: a systematic review. Bulletin of the World Health Organization 91:501-508. https://doi.org/10.2471/ BLT.12.111732 
Tzanidakis N, Maksimov P, Conraths FJ, Kiossis E, Brozos C, Sotiraki S, Schares G (2012) Toxoplasma gondii in sheep and goats: seroprevalence and potential risk factors under dairy husbandry practices. Veterinary Parasitology 190:340-348. https://doi.org/10.1016/j.vetpar.2012.07.020

Van der Puije W, Bosompem KM, Canacoo EA, Wastling JM, Akanmori BD (2000) The prevalence of anti-Toxoplasma gondii antibodies in Ghanaian sheep and goats. Acta Tropica 76:21-26. https://doi.org/10.1016/s0001-706x(00)00084-x

Verhelst D, De Craeye S, Vanrobaeys M, Czaplicki G, Dorny P, Cox E (2014) Seroprevalence of Toxoplasma gondii in domestic sheep in Belgium. Veterinary Parasitology 205:57-61. https:// doi.org/10.1016/j.vetpar.2014.07.001

Villena I, Durand B, Aubert D, Blaga R, Geers R, Thomas M, Perret C, Alliot A, Escotte-Binet S, Thebault A, Boireau P, Halos L (2012) New strategy for the survey of Toxoplasma gondii in meat for human consumption. Veterinary Parasitology 183:203208. https://doi.org/10.1016/j.vetpar.2011.08.001

Vismarra A, Mangia C, Barilli E, Brindani F, Bacci C, Kramer L (2016) Meat juice serology for Toxoplasma gondii infection in chickens. Italian Journal of Food Safety 5:5586. https://doi.org/ 10.4081/ijfs.2016.5586

Wang CR, Qiu JH, Gao JF, Liu LM, Wang C, Liu Q, Yan C, Zhu XQ (2011) Seroprevalence of Toxoplasma gondii infection in sheep and goats in northeastern China. Small Ruminant Research 97:130-133

Wang ZD, Liu HH, Ma ZX, Ma HY, Li ZY, Yang ZB, Zhu XQ, Xu B, Wei F, Liu Q (2017) Toxoplasma gondii infection in immunocompromised patients: a systematic review and metaanalysis. Frontiers in Microbiology 8:389. https://doi.org/10.3389/ fmicb.2017.00389

Weiss LM, Dubey JP (2009) Toxoplasmosis: a history of clinical observations. International Journal of Parasitology 39:895-901. https://doi.org/10.1016/j.ijpara.2009.02.004

Wiengcharoen J, Nakthong C, Mitchaothai J, Udonsom R, Sukthana Y (2012) Toxoplasmosis and neosporosis among beef cattle slaughtered for food in Western Thailand. The Southeast Asian Journal of Tropical Medicine and Public Health 43:10871093

Yaglom HD, Rottinghaus AA, Pithua P (2014) Evidence of Toxoplasma gondii exposure in Boer goat herds in Missouri, USA. Zoonoses and Public Health 61:395-397. https://doi.org/10.1111/ zph.12089

Zhou M, Cao S, Sevinc F, Sevinc M, Ceylan O, Liu M, Wang G, Moumouni PF, Jirapattharasate C, Suzuki H, Nishikawa Y, Xuan X (2016) Enzyme-linked immunosorbent assays using recombinant TgSAG2 and NcSAG1 to detect Toxoplasma gondii and Neospora caninum-specific antibodies in domestic animals in Turkey. The Journal of Veterinary Medical Science 78:18771881. https://doi.org/10.1292/jvms.16-0234

Zou F, Yu X, Yang Y, Hu S, Chang H, Yang J, Duan G (2015) Seroprevalence and risk factors of Toxoplasma gondii infection in buffaloes, sheep and goats in Yunnan province, southwestern China. Iranian Journal of Parasitology 10:648-665 